\title{
Distribution and Health Risk Assessment of Trace Metals in Surface Waters and Groundwater Around Artisanal Gold Mining Areas in Central-western Côte d'Ivoire, West Africa
}

\author{
Zoumana Traore $^{1}$, N'guessan Louis Berenger Kouassi ${ }^{2,}$, , Alain Stephane Assemian ${ }^{3}$, \\ Konan Edmond Kouassi ${ }^{3}$, Patrick Drogui ${ }^{4}$, Kouassi Benjamin Yao ${ }^{1}$ \\ ${ }^{1}$ Laboratory of Industrial Processes of Synthesis, Environment and New Energies (LAPISEN), Felix Houphouët-Boigny National \\ Polytechnic Institute, Yamoussoukro, Ivory Coast \\ ${ }^{2}$ Department of Mathematics, Physics and Chemistry, University of Peleforo Gon Coulibaly, Korhogo, Ivory Coast \\ ${ }^{3}$ Laboratory of Thermodynamic and Physical Chemistry of the Environment, University of Nangui Abrogoua, Abidjan, Ivory Coast \\ ${ }^{4}$ National Institute of Scientific Research, University of Quebec, Quebec City, Canada
}

\section{Email address: \\ kberenger2015@gmail.com (N. L. B. Kouassi) \\ ${ }^{*}$ Corresponding author}

\section{To cite this article:}

Zoumana Traore, N'guessan Louis Berenger Kouassi, Alain Stephane Assemian, Konan Edmond Kouassi, Patrick Drogui, Kouassi Benjamin Yao. Distribution and Health Risk Assessment of Trace Metals in Surface Waters and Groundwater Around Artisanal Gold Mining Areas in Central-western Côte d'Ivoire, West Africa. International Journal of Environmental Monitoring and Analysis.

Vol. 9, No. 5, 2021, pp. 136-151. doi: 10.11648/j.ijema.20210905.15

Received: September 4, 2021; Accepted: October 5, 2021; Published: October 15, 2021

\begin{abstract}
The present study aimed to evaluate $\mathrm{Ni}, \mathrm{Cr}, \mathrm{Zn}, \mathrm{Cd}, \mathrm{Hg}$, and $\mathrm{Pb}$ distribution and the health risks in surface waters and groundwater around artisanal mining areas in the central-western Côte d'Ivoire. Trace metals spatial distributions were assessed using ArGIS method. Waters pollution status were ascertained through water pollution indices. Human health risk was investigated using non-carcinogenic and carcinogenic risks indices. In surface waters, the same distribution trends were observed for $\mathrm{Ni}$ and $\mathrm{Cd}$, and, for $\mathrm{Hg}$ and $\mathrm{Pb}$. While, the distribution patterns of $\mathrm{Zn}$ and $\mathrm{Cr}$ differed from those of $\mathrm{Ni}, \mathrm{Cd}$, $\mathrm{Hg}$, and $\mathrm{Pb}$. Trace metals $(\mathrm{Ni}, \mathrm{Cr}, \mathrm{Cd}, \mathrm{Zn}, \mathrm{Hg}$ and $\mathrm{Pb})$ concentrations in groundwater were within their guidelines values. While, the averages total of $\mathrm{Ni}, \mathrm{Cd}, \mathrm{Hg}$, and $\mathrm{Pb}$ concentrations for the surface waters exceeded their guidelines values. The pollution status revealed high and low pollution levels of surface waters and groundwater, respectively. Averages of the total noncarcinogenic risk for $\mathrm{Hg}, \mathrm{Cd}, \mathrm{Ni}$ and $\mathrm{Pb}$ in surface waters varied between $1.529 \pm 1.162$ and $80.507 \pm 104.615$, indicating adverse effects to human health. The averages total carcinogenic risks for $\mathrm{Ni}, \mathrm{Cd}, \mathrm{Pb}$, and $\mathrm{Cr}$ indicated that the population around the artisanal gold mining area could develop cancer. Therefore, it is important to treat waters for removing trace metals before using for domestic purposes.
\end{abstract}

Keywords: Trace Metals, Pollution Assessment, Risks Assessment, Surface Waters, Groundwater

\section{Introduction}

Water is an important element for human survival [1]. However, its quality is threatened by many activities like agricultural practices and gold extraction [1]. In many developing countries, mining activities contribute to economic growth and poverty reduction via job creations [2]. But, the intensification of these mining activities can impact negatively the water ressources and rural population through the release of toxic chemical pollutants [3, 4]. Among these contaminants, heavy metals have attracted global attention due to their toxicity, persistence and bioaccumulation [5-7]. Therefore, environmental studies of mining areas are important.

$\mathrm{Cr}, \mathrm{Ni}$ and $\mathrm{Zn}$ are considered to be essential for humans [8]. While, $\mathrm{Cd}, \mathrm{Pb}$, and $\mathrm{Hg}$ are not essential for humans [9]. But they may cause deleterious effects on the environment and human health beyond their tolerance values [10]. Trace metals $\mathrm{Cr}$ and $\mathrm{Zn}$ exposure can cause lung cancer [11]. $\mathrm{Cd}$ 
exposure may lead to prostatic, kidney problems, hypertension and lung cancer [11-13].

Chronic exposure to $\mathrm{Hg}$ can have adverse effects such as neurological disorders and renal dysfunction [2, 14, 15]. Ni toxic effects include respiratory disorders, lungs and even cancers [16]. Excess $\mathrm{Pb}$ can damage the neurological system, cause renal disfonctionment, skeletal weakness, mutations and cancer [8, 11, 17]. Therefore, monitoring of $\mathrm{Zn}, \mathrm{Cr}, \mathrm{Ni}$, $\mathrm{Cd}, \mathrm{Hg}$ and $\mathrm{Pb}$ concentrations in environment are essential.

High concentrations of $\mathrm{Ni}, \mathrm{Zn}, \mathrm{Cr}, \mathrm{Cd}, \mathrm{Pb}$ and $\mathrm{Hg}$ in groundwater and surface waters due to mining activities were reported in many countries such as China [3, 4, 18], Colombia [19, 20], Brazil [21], South Korea [22] and India [23]. In addition, the negative impacts of trace metals on human health in the mining regions of Europe, South America, and Central Africa have been reported in the literature. For example, high concentrations of $\mathrm{Cd}$ and $\mathrm{Hg}$ were observed in urine of children living near mining area in Andalusia (Spain) [24]. Miners from a mining area in Colombia accumulated high concentrations of $\mathrm{Hg}$ in blood, urine and hair [25]. High levels of $\mathrm{Pb}, \mathrm{Cd}$ and $\mathrm{Ni}$ were observed in hair of older children (10 years) living around Migori gold mining area in Kenya, Central Africa [26]. Countries in West Africa, are not left out of this mining contamination. For example, high concentrations of $\mathrm{Pb}$ and $\mathrm{Zn}$ were reported in the urine of population living near a small-scale gold mining area in Ghana [27]. Many investigations have documented the contamination of surface waters and groundwater around mining areas in West Africa, with studies focused in Nigeria [2, 28, 29], Ghana [14, 30-32], Senegal [33] and Burkina Faso [34], but in Côte d'Ivoire, studies are in their infancy. Recently, Kone et al [35] showed that surface waters around Tongon industrial mining area in northern Côte d'Ivoire were contaminated by $\mathrm{Pb}, \mathrm{As}$ and $\mathrm{Cr}$. These studies are not focused on the assessment of potential non-carcinogenic and carcinogenic risks. In addition, studies on waters quality assessment around artisanal gold mining areas in Côte d'Ivoire are not previously investigated. Therefore, it is important to establish first data on the human health risks associated with $\mathrm{Ni}, \mathrm{Zn}, \mathrm{Cd}, \mathrm{Pb}, \mathrm{Cr}$, and $\mathrm{Hg}$ in waters near artisanal mining areas in Côte d'Ivoire. This study aimed to assess: (i) $\mathrm{Zn}, \mathrm{Cr}, \mathrm{Ni}, \mathrm{Cd}, \mathrm{Hg}$ and $\mathrm{Pb}$ distribution in surface waters and groundwater; (ii) the quality and the pollution levels of the surface waters and groundwater; (iii) the health risks from $\mathrm{Zn}, \mathrm{Cr}, \mathrm{Ni}, \mathrm{Cd}, \mathrm{Hg}$ and $\mathrm{Pb}$. The health risk evaluation is important since waters are mostly utilized without any treatment by population living near artisanal gold mining areas.

\section{Material and Methods}

\subsection{Study Area and Sampling}

The department of Bouaflé is located in the Central
Western Côte d'Ivoire, West Africa (Figure 1). It has an area of $4,222.48 \mathrm{~km}^{2}$. The departement is well is well known through activities such as livestock, cocoa, banana, palm oil, rice, yam, vegetables, food and mining activities. Bouafle lies in the Bandama river basin which is the longest and the largest river in Côte d'Ivoire [36]. It takes its source in the northern Côte d'Ivoire, between Korhogo and Boundiali at an altitude of $480 \mathrm{~m}$ and flows into Grand-Lahou Lagoon and the Gulf of Guinea in the south. The Bandama river length and area are $1050 \mathrm{~km}$ and $97,500 \mathrm{~km}^{2}$, respectively [37, 38]. The Kossou Lake is largest lake in Côte d'Ivoire. It has an area of $1700 \mathrm{~km}^{2}$, a reservoir of 30 billion $\mathrm{m}^{3}$ of water and a length of $150 \mathrm{~km}$. The Kossou lake plays an important role in the Ivorian economy. Indeed, Kossou represents the biggest hydroelectric plant which provides power for Côte d'Ivoire, it allows the creation of large areas of irrigated agriculture (50,000 hectares of land) and it is one of the main places of continental fishing activities [39]. It is also the largest dam in Cote d'Ivoire. The selected sites are mining villages of Angovia, Allahou-Bazi, Kouakou Gnanou, Pangba Kouamekro, Allekran, Kaviessou and Duonfla in Bouafle departement. The stations are located in the Bandama river (SP11, SP12, SP13 and SP14), in the Kossou lake (SP15, SP16, SP17 and SP18), in the pond water (SP19, SP20, SP21 and SP22) and in the groundwater (SP23, SP24, SP25 and SP26) (Figure 1). The water from the pond is used for washing gold tailings and the wastewaters after washing processes are discharged again into the pond.

The waters sampling was carried out in December 2019 and August 2020 at 16 stations from the Bandama river, the Kossou lake, the pond water, and the groundwater. The water sampling method described by APHA was used in this study [40]. Surface waters were sampled with a Niskin bottle (5 L) at $50 \mathrm{~cm}$ depht. To prevent metal precipitation, water samples were acidified with $1 \mathrm{~mL}$ of nitric acid (65\% suprapur, E. Merck, Germany) and stored at $4^{\circ} \mathrm{C}$ until analysis [36]. Previously, all glassware and plastic bottle were rinced with de-ionized water, cleaned with $20 \%$ of $\mathrm{HNO}_{3}$ and rinsed three times with de-ionized water before use [36, 41].

\subsection{Analytical Methods}

A HANNA multiparameter HI.9828 was used for in situ determination of the $\mathrm{pH}$ and electrical conductivity. The anoins $\left(\mathrm{SO}_{4}{ }^{2-}, \mathrm{Cl}^{-}, \mathrm{F}^{-}\right.$and $\left.\mathrm{NO}_{3}{ }^{-}\right)$and the cations $\left(\mathrm{Mg}^{2+}, \mathrm{Na}^{+}\right.$ and $\mathrm{Ca}^{2+}$ ) were determined using a spectrophometer $\mathrm{HACH}$ DR 6000. Ni, Cr, Cd, $\mathrm{Zn}, \mathrm{Hg}$ and $\mathrm{Pb}$ total concentrations were determined using the Inductively Couple Plasma Mass Spectroscopy (ICP-MS). The detection limit for trace metals were $0.001 \mathrm{mg} / \mathrm{L}$ for $\mathrm{Ni}$ and $\mathrm{Cr}, 0.0001 \mathrm{mg} / \mathrm{L}$ for $\mathrm{Cd}, 0.005$ $\mathrm{mg} / \mathrm{L}$ for $\mathrm{Zn}, 0.0005 \mathrm{mg} / \mathrm{L}$ for $\mathrm{Hg}$ and $\mathrm{Pb}$. The experiment was performed in triplicate.

The spatial distributions of $\mathrm{Ni}, \mathrm{Cr}, \mathrm{Cd}, \mathrm{Zn}, \mathrm{Hg}$ and $\mathrm{Pb}$ were assessed using ArcGIS V (10.2). 

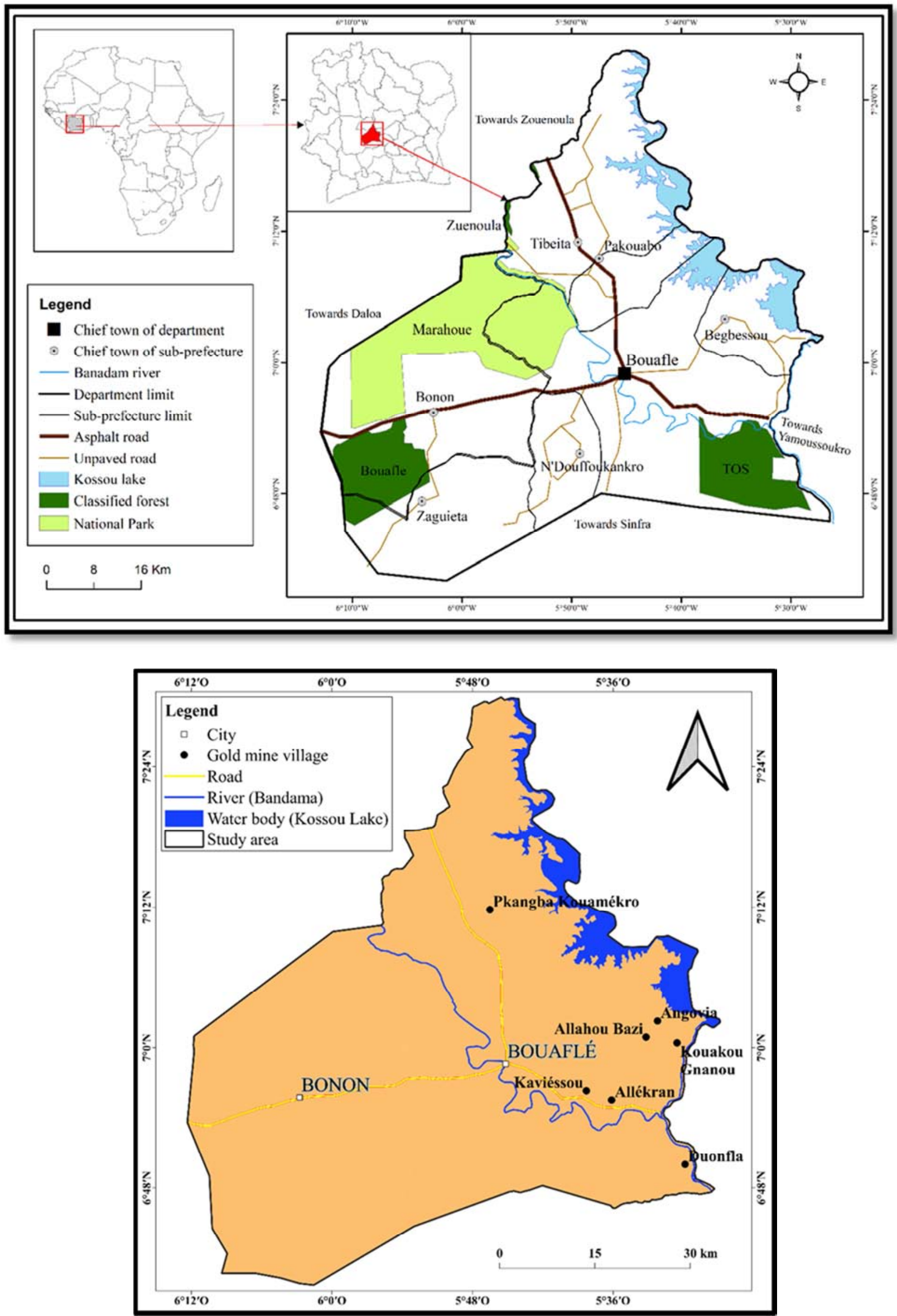


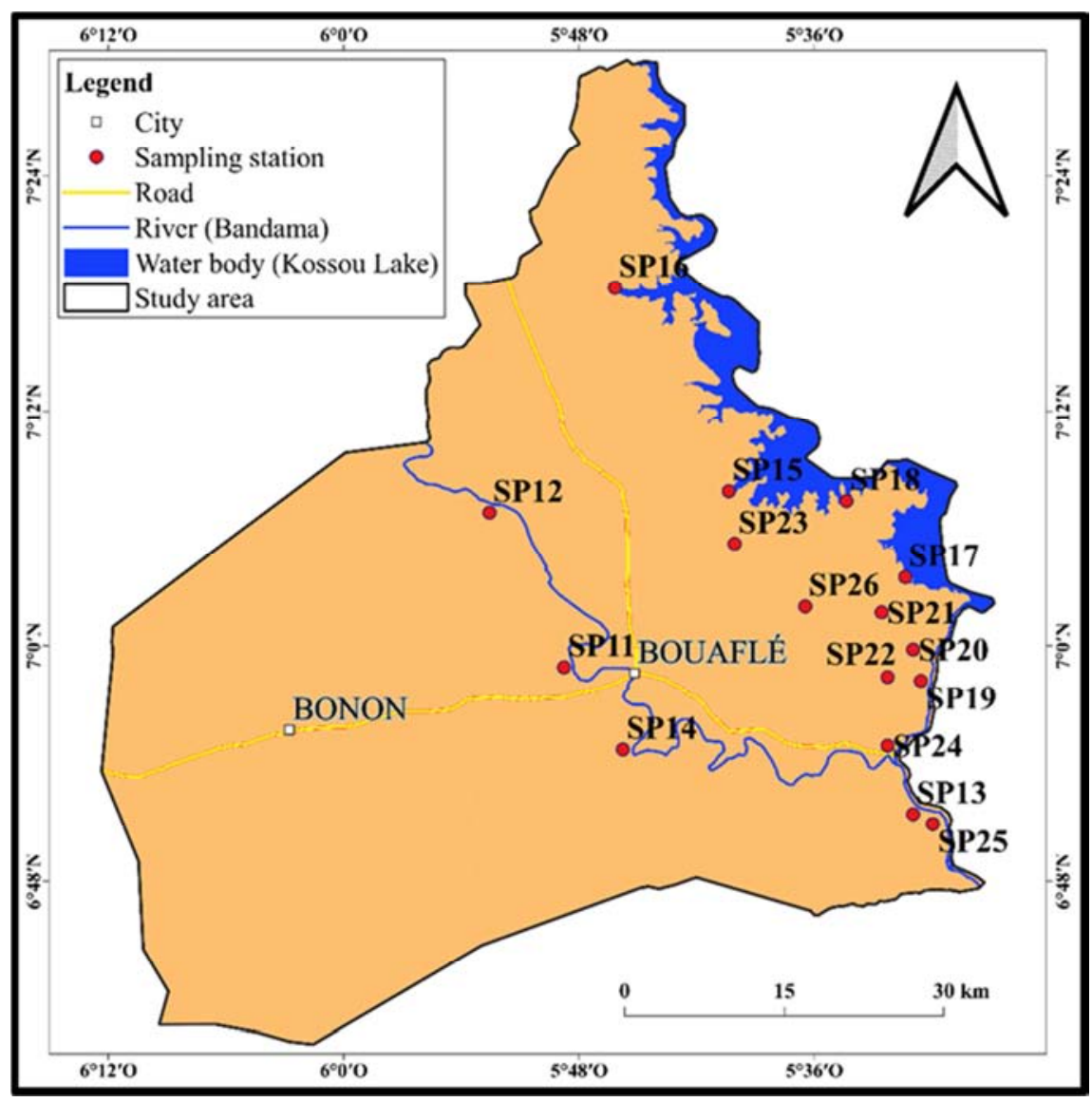

Figure 1. Study area and sampling stations.

\subsection{Pollution Level Assessment}

\subsubsection{Heavy Metal Pollution Index (HPI)}

The HPI index is calculated using the following equation [42]:

$$
\mathrm{HPI}=\frac{\sum_{\mathrm{i}=1}^{\mathrm{n}} \mathrm{W}_{\mathrm{i}} \times \mathrm{Q}_{\mathrm{i}}}{\sum_{\mathrm{i}=1}^{\mathrm{n}} \mathrm{W}_{\mathrm{i}}}
$$

Where $\mathrm{n}$ is the number of metals analysed. The unit weighting of ith metal is defined by wi. Qi is the sub-index for ith trace metal. The unit weighting (wi) was calculated by the relation below [43]:

$$
\mathrm{w}_{\mathrm{i}}=\frac{1}{\mathrm{MAC}_{\mathrm{i}}}
$$

Where MACi is the maximum admissible concentration of ith pollutant.

Qi is computed using the relationship below:

$$
\mathrm{Q}_{\mathrm{i}}=\sum_{\mathrm{i}=1}^{\mathrm{n}} \frac{\mathrm{C}_{\mathrm{i}}(-) \mathrm{L}_{\mathrm{i}}}{\mathrm{M}_{\mathrm{i}}-\mathrm{L}_{\mathrm{i}}}
$$

Where $C_{i}$ was the determined concentration of the pollutant $i$. The maximum permissible and lower desirable values of metal $\mathrm{i}$ were given by $\mathrm{Mi}$ and $\mathrm{Li}$, respectively. The algebraic sign (-) indicates the numerical differences between the two values. The algebraic sign is ignored. Mi and Li values were taken from WHO [44] and USEPA [45].
HPI $<100$ indicates low pollution of heavy metal. HPI $=100$ indicates that harmful health effects are probable. HPI $>100$ suggests that the water is not suitable for drinking [46].

\subsubsection{Heavy Metal Evaluation Index (HEI)}

The overall surface water quality with respect to heavy metal concentration is evaluated by HEI. HEI index is calculated as follows $[46,47]$ :

$$
\mathrm{HEI}=\sum_{\mathrm{i}=1}^{\mathrm{n}} \frac{\mathrm{C}_{\mathrm{i}}}{\mathrm{MAC}_{\mathrm{i}}}
$$

Where $C_{i}$ is the measured concentration of the ith heavy metal. $\mathrm{MAC}_{\mathrm{i}}$ is the maximum admissible concentration of metal i. The HEI value below 10 indicates low pollution level. The water is moderately polluted when HEI is between 10 and 20. HEI higher than 20 indicates high pollution level [46]. Table 1 gives the values of $\mathrm{Mi}, \mathrm{Li}$ and $\mathrm{MAC}_{\mathrm{i}}$ for heavy metals.

Table 1. Mi, Li, MACi and wi values for heavy metals [44, 45].

\begin{tabular}{lllll}
\hline Metals & $\mathbf{M}_{\mathbf{i}}(\boldsymbol{\mu g} / \mathbf{L})$ & $\mathbf{L}_{\mathbf{i}}(\boldsymbol{\mu} \mathbf{g} / \mathbf{L})$ & $\mathbf{M A C}(\boldsymbol{\mu g} \mathbf{g} \mathbf{L})$ & $\mathbf{w}_{\mathbf{i}}$ \\
\hline $\mathrm{Ni}$ & 70 & 20 & 20 & 0.05 \\
$\mathrm{Cr}$ & 100 & 50 & 50 & 0.02 \\
$\mathrm{Cd}$ & 5 & 3 & 3 & 0.3 \\
$\mathrm{Zn}$ & 5000 & 3000 & 5000 & 0.0002 \\
$\mathrm{Hg}$ & 2 & 1 & 2 & 0.50 \\
$\mathrm{~Pb}$ & 100 & 10 & 1.5 & 0.7 \\
\hline
\end{tabular}




\subsection{Water Quality Assessment}

The water quality is assessed using the water quality index (WQI). The following equation (5) is used to calculate WQI $[48,49]$ :

$$
\begin{gathered}
\mathrm{WQI}=\sum\left[\mathrm{W}_{\mathrm{i}} \times\left(\frac{\mathrm{C}_{\mathrm{i}}}{\mathrm{S}_{\mathrm{i}}}\right) \times 100\right] \\
\mathrm{W}_{\mathrm{i}}=\frac{\mathrm{w}_{\mathrm{i}}}{\sum \mathrm{w}_{\mathrm{i}}}
\end{gathered}
$$

Where $C_{i}$ was the determined value of $i$ th parameter. $S_{i}$ was the standard value according to $\mathrm{WHO}$. Wi and wi were the relative weight and the weight attributed to the element $\mathrm{i}$, respectively.

$\sum w_{i}$ was the sum of $\mathrm{w}_{\mathrm{i} .}$ A WQI value below 50 indicates excellent quality; water quality is good when $50 \leq \mathrm{WQI}<1$; when $100 \leq \mathrm{WQI}<200$, water quality is poor; if $200 \leq \mathrm{WQI}$ $<300$, water quality is very poor; WQI $\geq 300$ indicates that water is not drinkable [50]. The values of $\mathrm{S}_{\mathrm{i}}$ and the relative weights (Wi) are given in Table 2 .

Table 2. Relative weight and standard $S_{i}$ values.

\begin{tabular}{llll}
\hline Parameters & $\begin{array}{l}\text { WHO standard } \\
(\mathbf{2 0 1 7}))\end{array}$ & Weight $\left(\mathbf{w}_{\mathbf{i}}\right)$ & $\begin{array}{l}\text { Relative } \\
\text { weight }\left(\mathbf{W}_{\mathbf{i}}\right)\end{array}$ \\
\hline $\mathrm{pH}$ & $6.5-8.5$ & 4 & 0.0816 \\
$\mathrm{SO}_{4}{ }^{2-}(\mathrm{mg} / \mathrm{L})$ & 250 & 4 & 0.0816 \\
$\mathrm{Cl}^{-}(\mathrm{mg} / \mathrm{L})$ & 250 & 3 & 0.0612 \\
$\mathrm{NO}_{3}{ }^{-}(\mathrm{mg} / \mathrm{L})$ & 50 & 5 & 0.1020 \\
$\mathrm{Ca}^{2+}(\mathrm{mg} / \mathrm{L})$ & 300 & 2 & 0.0408 \\
$\mathrm{Mg}^{2+}(\mathrm{mg} / \mathrm{L})$ & 30 & 2 & 0.0408 \\
$\mathrm{Na}^{+}(\mathrm{mg} / \mathrm{L})$ & 200 & 2 & 0.0408 \\
$\mathrm{~F}^{-}(\mathrm{mg} / \mathrm{L})$ & 1.5 & 5 & 0.1020 \\
$\mathrm{Ni}(\mathrm{mg} / \mathrm{L})$ & 0.07 & 1 & 0.0204 \\
$\mathrm{Cr}(\mathrm{mg} / \mathrm{L})$ & 0.05 & 5 & 0.1020 \\
$\mathrm{Cd}(\mathrm{mg} / \mathrm{L})$ & 0.003 & 5 & 0.1020 \\
$\mathrm{Zn}(\mathrm{mg} / \mathrm{L})$ & 3 & 1 & 0.0204 \\
$\mathrm{Hg}(\mathrm{mg} / \mathrm{L})$ & 0.006 & 5 & 0.1020 \\
$\mathrm{~Pb}(\mathrm{mg} / \mathrm{L})$ & 0.01 & 5 & 0.1020 \\
& & $\sum w_{i}=49$ & $\sum W_{i}=1$ \\
\hline
\end{tabular}

\subsection{Health Risk Assessment}

\subsubsection{Non-carcinogenic Risks}

The following equations are used to assess the exposure $[51,52]$ :

$$
\mathrm{CDI}_{\text {ing }}=\frac{\mathrm{C}_{\mathrm{i}} \times \mathrm{IR} \times \mathrm{EF} \times \mathrm{ED}}{\mathrm{BW} \times \mathrm{AT}_{\mathrm{nc}}}
$$

$$
\mathrm{CDI}_{\mathrm{der}}=\frac{\mathrm{C}_{\mathrm{i}} \times \mathrm{SA} \times \mathrm{K}_{\mathrm{p}} \times \mathrm{ET} \times \mathrm{EF} \times \mathrm{ED} \times \mathrm{CF}}{\mathrm{BW} \times \mathrm{AT}_{\mathrm{nc}}}
$$

Where $\mathrm{CDI}_{\text {ing }}(\mu \mathrm{g} / \mathrm{Kg}$.day) indicates the chronic daily intake through ingestion. $\mathrm{CDI}_{\mathrm{der}}(\mu \mathrm{g} / \mathrm{Kg}$.day) expresses the chronic daily intake through dermal contact. The other exposure parameters were reported in Table 3 .

The hazard quotient (HQ) was used to assess the noncarcinogenic risk

The hazard index (HI) expresses the total non-carcinogenic risk. $\mathrm{HI}$ is computed as follows [51]

$$
\begin{gathered}
\mathrm{HQ}_{\text {ing }}=\frac{\mathrm{CDI}_{\text {ing }}}{\mathrm{RfD}_{\text {ing }}} \\
\mathrm{HQ}_{\text {der }}=\frac{\mathrm{CDI}_{\text {der }}}{\mathrm{RfD}_{\text {der }}} \\
\mathrm{RfD}_{\text {der }}=\mathrm{RfD}_{\text {ing }} \times \mathrm{ABS}_{\mathrm{g}} \\
\mathrm{HI}=\sum\left(\mathrm{HQ}_{\text {ing }}+\mathrm{H} \mathrm{Q}_{\text {der }}\right)
\end{gathered}
$$

The HI value below 1 indicates low adverse effects. When $\mathrm{HI} \geq 1$, adverse effects can occur on human health [51].

\subsubsection{Carcinogenic Risks}

Trace metals $\mathrm{Ni}, \mathrm{Cd}, \mathrm{Cr}$, and $\mathrm{Pb}$ were used to assess the carcinogenic risk. The carcinogenic risk is calculated as follows $[52,53,56,57]$ :

$$
\mathrm{CR}=\sum \mathrm{CDI}_{\mathrm{i}} \times \mathrm{SF}_{\mathrm{i}}
$$

Where $\mathrm{SF}_{\mathrm{i}}$ is a slope factor.

$$
\begin{gathered}
\mathrm{CR}_{\text {ing }}=\mathrm{CDI}_{\text {ing }} \times \mathrm{SF}_{\text {ing }} \\
\mathrm{CR}_{\text {der }}=\mathrm{CDI}_{\text {der }} \times \mathrm{SF}_{\text {der }} \\
\mathrm{SF}_{\text {der }}=\frac{\mathrm{SF}_{\text {ing }}}{\mathrm{ABS} \mathrm{g}} \\
\mathrm{CR}=\sum\left(\mathrm{CR}_{\text {ing }}+\mathrm{CR}_{\text {der }}\right)
\end{gathered}
$$

\begin{tabular}{|c|c|c|c|c|}
\hline Parameter & Meaning & Value & Unit & Reference \\
\hline IR & Ingestion rate & 2.2 & $\mathrm{~L} /$ day & {$[53]$} \\
\hline $\mathrm{EF}$ & Exposure frequency & 365 & day & {$[53]$} \\
\hline ED & Exposure duration & 58 & year & {$[54]$} \\
\hline BW & Body weight & 60 & $\mathrm{Kg}$ & {$[53]$} \\
\hline $\mathrm{AT}_{\mathrm{nc}}$ & Average time for non-carcinogenic & $365 \times 58$ & day & \\
\hline SA & Skin-surface area & 18,000 & $\mathrm{Cm}^{2}$ & {$[53]$} \\
\hline $\mathrm{K}_{\mathrm{p}}$ & Permeability coefficient & Ni: 0.0002; Cr:0.002; Zn: 0.0006; Cd, Hg and Pb: 0.001 & $\mathrm{~cm} / \mathrm{h}$ & [53] \\
\hline ET & Exposure time & 0.58 & $\mathrm{~h} /$ day & {$[53]$} \\
\hline $\mathrm{RfD}_{\text {ing }}$ & $\begin{array}{l}\text { Reference dose of heavy metals through } \\
\text { ingestion }\end{array}$ & Ni: 20; Cr:3; Cd:0.5; Zn:300; Hg:0.3; Pb: 1.4 & $\mu \mathrm{g} / \mathrm{Kg}$.day & {$[53]$} \\
\hline $\mathrm{SF}_{\text {ing }}$ & Slop factor of metal through ingestion & Ni: $0.91 ; \mathrm{Cr}: 0.42 ; \mathrm{Cd}: 0.38 ; \mathrm{Pb}: 0.0085$ & $\mu \mathrm{g} / \mathrm{Kg}$.day & {$[53]$} \\
\hline $\mathrm{ABS}_{\mathrm{g}}$ & Gastrointestinal absorption factor & $\mathrm{Ni}(0.27) ; \mathrm{Cr}(0.025) ; \mathrm{Cd}(0.05) ; \mathrm{Zn}(0.02) ; \mathrm{Hg}(0.07) ; \mathrm{Pb}(0.3)$ & & {$[55]$} \\
\hline
\end{tabular}

$\mathrm{CR}$ value $\leq 10^{-6}$ indicates no significant risk. When $\mathrm{CR}$ value $\geq 10^{-4}$, humans can develop a cancer. The range of acceptable carcinogenic risk is $10^{-6}$ to $10^{-4}$ [56].

Table 3. Exposure assessment parameters. 


\section{Results and Discussion}

\subsection{Surface Waters and Groundwater Physicochemical Parameters}

The physicochemical parameters mean values of all the waters were given by Table 4. $\mathrm{pH}$ average values were $7.33 \pm 0.45,6.70 \pm 0.99$ and $6.90 \pm 0.62$ in Bandaman, Kossou and groundwater, respectively. In the pond water the $\mathrm{pH}$ average was $3.87 \pm 0.94$, which indicates that the water is highly acidic and may be explained by the release of mine wastes [58]. The mean values of the Badaman river, the Kossou lake and the groundwater are in the permissible range $(6.5$ - 8.5) of WHO, while that of pond water was lower than the lower limit $(<6.5)$ set by WHO. These results indicated that pond waters are problematic for drinking usage, while groundwater could be used for drinking. In addition, the Badaman river and the Kossou lake could be used for diverse uses such as irrigation, domestic purposes, and recreational purposes.

Electrical conductivity mean values were $371 \pm 178.09$ $\mu \mathrm{S} / \mathrm{cm}$ in the Bandama river, $765.5 \pm 193.35 \mu \mathrm{S} / \mathrm{cm}$ in the Kossou lake, $1,446 \pm 571.57 \mu \mathrm{S} / \mathrm{cm}$ in pond water and $72.5 \pm 28.84 \mu \mathrm{S} / \mathrm{cm}$ in groudwater. According to Şener et al [49], water conductivity is correlated with dissolved solids. High waters EC values may be caused by contaminants [49]. Therefore, the maximun values observed in the Kossou lake and the pond water can be explained by the discharges product of grinding operation, amalgamation of the material and sewage [20].

The average concentrations of $\mathrm{SO}_{4}{ }^{2-}$ were $11.00 \pm 2.68$ $\mathrm{mg} / \mathrm{L}, \quad 10.08 \pm 2.29 \mathrm{mg} / \mathrm{L}, \quad 339.00 \pm 127.30 \mathrm{mg} / \mathrm{L}, \quad$ and $3.65 \pm 0.51 \mathrm{mg} / \mathrm{L}$ in the Bandama river, the Kossou lake, the pond water, and the groundwater, respectively. The mean value obtained in the pond water exceeded the WHO limit. The organic substances of weathered soils breakdouwn, the leaching of sulfate from fertilizers and the wastewater might explain the high value of sulfate in the pond water [59].

Chloride $\left(\mathrm{Cl}^{-}\right)$concentrations obtained in this study ranged from $10.08 \pm 2.29 \mathrm{mg} / \mathrm{L}$ to $331.85 \pm 182.53 \mathrm{mg} / \mathrm{L}$. The average values were $33.33 \pm 10.46 \mathrm{mg} / \mathrm{L}$ in the Bandama river, $10.08 \pm 2.29 \mathrm{mg} / \mathrm{L}$ in the Kossou lake, $331.85 \pm 182.53 \mathrm{mg} / \mathrm{L}$ in the pond water and $26.70 \pm 1.01 \mathrm{mg} / \mathrm{L}$ in the groundwater. The mean value of chloride in the pond water exceeded its standards value of $250 \mathrm{mg} / \mathrm{L} \mathrm{[44]} \mathrm{due} \mathrm{to} \mathrm{sewages} \mathrm{product}$ during the gold extraction process.
The mean nitrate $\left(\mathrm{NO}_{3}{ }^{-}\right)$concentrations were $36.80 \pm 9.68$ $\mathrm{mg} / \mathrm{L}$ in the Bandama river, $29.58 \pm 8.46 \mathrm{mg} / \mathrm{L}$ in the Kossou lake, $48.88 \pm 3.66 \mathrm{mg} / \mathrm{L}$ in the pond water and $4.87 \pm 0.98 \mathrm{mg} / \mathrm{L}$ in the groundwater. The mean values of nitrate in all waters were below the WHO limit $(50 \mathrm{mg} / \mathrm{L})$. However, the maximun value obtained in the pond water may be attributed to fertilizer used in agricultural activities.

Calcium $\left(\mathrm{Ca}^{2+}\right)$ average concentrations recorded for the all water-bodies did not exceed the limit $300 \mathrm{mg} / \mathrm{L}$ [45]. The values were $17.83 \pm 2.47 \mathrm{mg} / \mathrm{L}, \quad 20.38 \pm 3.73 \mathrm{mg} / \mathrm{L}$, $30.70 \pm 12.66 \mathrm{mg} / \mathrm{L}$ and $60.88 \pm 1.59 \mathrm{mg} / \mathrm{L}$ in the Bandama river, the Kossou lake, the pond water and the groundwater, respectively. However, the dissolution of calcite and dolomite may explain the maximum value obtained in groundwater [49].

Magnesium $\left(\mathrm{Mg}^{2+}\right)$ concentrations of water samples varied between $4.27 \pm 0.46 \mathrm{mg} / \mathrm{L}$ and $99.07 \pm 46.28 \mathrm{mg} / \mathrm{L}$. The averages were $35.75 \pm 8.63 \mathrm{mg} / \mathrm{L}$ in the Bandama river, $35.93 \pm 13.82 \mathrm{mg} / \mathrm{L}$ in the Kossou Lake, $99.08 \pm 46.28 \mathrm{mg} / \mathrm{L}$ in the pond water, and $4.28 \pm 0.46 \mathrm{mg} / \mathrm{L}$ in the groundwater. The values obtained in the surface waters exceeded the desirable limit of $30 \mathrm{mg} / \mathrm{L}$ [44]. Higher $\mathrm{Mg}^{2+}$ concentrations may be due to the decomposition of the ferromagnesia, minerals, the metamorphic rock and the magnesium carbonate in sedimentary rock [60].

The averages content of $\mathrm{Na}^{+}$in surface waters samples were $3746.51 \pm 718.76 \mathrm{mg} / \mathrm{L}, 4112.22 \pm 469.21 \mathrm{mg} / \mathrm{L}$, and $5071.04 \pm 197.78 \mathrm{mg} / \mathrm{L}$ in the Bandama river, the Kossou lake and the pond water, respectively. The mean values of $\mathrm{Na}^{+}$in all surface waters exceeded the acceptable limit of $200 \mathrm{mg} / \mathrm{L}$ which may be explained by the decomposition of igneous rocks and the wastes discharges $[60,61]$. While, $\mathrm{Na}^{+}$mean concentration in groundwater $(23.37 \pm 2.91 \mathrm{mg} / \mathrm{L})$ was below its WHO limit $(200 \mathrm{mg} / \mathrm{L})$.

The fluoride $\left(\mathrm{F}^{-}\right)$mean concentrations $(\mathrm{mg} / \mathrm{L})$ obtained were $0.17 \pm 0.16,0.31 \pm 0.16,0.28 \pm 0.06$, and $0.03 \pm 0.02$ in the Bandama river, the Kossou lake, the pond water and the groundwater, respectively. These mean values did not exceed the acceptable limit (1.5 $\mathrm{mg} / \mathrm{L})$ according to WHO [44].

Our findings showed that, all the physicochemical parameters in the groundwater samples were found to be within the WHO guideline values, indicating good quality. Therefore, to better understand the quality of surface waters and groundwater around artisanal mining areas in Bouafle, water pollution indices assessment was performed.

Table 4. Average values of the physical and chemical parameters.

\begin{tabular}{llll}
\hline & Bandama & Kossou & Pond water \\
\hline $\mathrm{pH}$ & $7.33 \pm 0.45$ & $6.70 \pm 0.99$ & $3.87 \pm 0.94$ \\
$\mathrm{Conductivity}(\mu \mathrm{S} / \mathrm{Cm})$ & $371.75 \pm 178.97$ & $765.5 \pm 193.34$ & $1446.00 \pm 571.57$ \\
$\mathrm{SO}_{4}{ }^{2-}(\mathrm{mg} / \mathrm{L})$ & $11.00 \pm 2.69$ & $10.07 \pm 2.29$ & $339.00 \pm 127.30$ \\
$\mathrm{Cl}^{-}(\mathrm{mg} / \mathrm{L})$ & $33.32 \pm 10.46$ & $29.02 \pm 8.59$ & $331.85 \pm 182.52$ \\
$\mathrm{NO}_{3}^{-}(\mathrm{mg} / \mathrm{L})$ & $36.8 \pm 9.68$ & $29.57 \pm 8.46$ & $48.87 \pm 3.66$ \\
$\mathrm{Ca}^{2+}(\mathrm{mg} / \mathrm{L})$ & $17.82 \pm 2.47$ & $20.37 \pm 3.73$ & $30.70 \pm 12.66$ \\
$\mathrm{Mg}^{2+}(\mathrm{mg} / \mathrm{L})$ & $35.75 \pm 8.63$ & $35.92 \pm 13.82$ & $99.07 \pm 46.28$ \\
$\mathrm{Na}^{+}(\mathrm{mg} / \mathrm{L})$ & $3746.50 \pm 718.76$ & $4112.21 \pm 469.21$ & $5.65 \pm 0.51$ \\
$\mathrm{~F}^{-}(\mathrm{mg} / \mathrm{L})$ & $0.17 \pm 0.15$ & $0.30 \pm 0.16$ & $5071.04 \pm 197.78$ \\
\hline
\end{tabular}




\subsection{Trace Metals Distribution in Surface Waters and Groundwater}

The spatial distributions of total $\mathrm{Ni}, \mathrm{Cr}, \mathrm{Cd}, \mathrm{Zn}, \mathrm{Pb}$ and $\mathrm{Hg}$ in surface waters and groundwater are shown in Figure 2. $\mathrm{Ni}$ concentrations varied between $3.36 \times 10^{-3}$ and 3.86 $\mathrm{mg} / \mathrm{L}$. The averages of total $\mathrm{Ni}$ were $1.47 \pm 0.45 \mathrm{mg} / \mathrm{L}$, $1.22 \pm 0.29 \mathrm{mg} / \mathrm{L}, 2.36 \pm 1.09 \mathrm{mg} / \mathrm{L}$ and $4.7 \times 10^{-3 \pm} 1.42 \times 10^{-3}$ $\mathrm{mg} / \mathrm{L}$, in the Bandama river, the Kossou lake, the pond water and the groundwater, respectively. $\mathrm{Cr}$ concentrations varied between $<\mathrm{LD}$ and $0.08 \mathrm{mg} / \mathrm{L}$. The mean values were $0.02 \pm 0.01 \mathrm{mg} / \mathrm{L}$ in the Bandama river, $0.02 \pm 0.03 \mathrm{mg} / \mathrm{L}$ in the Kossou lake, $0.03 \pm 0.14 \mathrm{mg} / \mathrm{L}$ in the pond water and $1.83 \times 10^{-3} \pm 1.42 \times 10^{-3} \mathrm{mg} / \mathrm{L}$ in the groundwater. As shown in Figure $1, \mathrm{Cd}$ concentrations varied between $8.16 \times 10^{-4}$ and $0.32 \mathrm{mg} / \mathrm{L}$. The averages $\mathrm{Cd}$ concentrations were $0.05 \pm 0.03 \mathrm{mg} / \mathrm{L}, 0.04 \pm 0.03 \mathrm{mg} / \mathrm{L}$, $0.21 \pm 0.14 \mathrm{mg} / \mathrm{L}$ and $9.75 \times 10^{-4} \pm 3.23 \times 10^{-4} \mathrm{mg} / \mathrm{L}$ in the Bandama river, the Kossou lake, the pond water and the groundwater, respectively. Trace metal $\mathrm{Zn}$ concentrations ranged from $5.45 \times 10^{-3}$ to $0.93 \mathrm{mg} / \mathrm{L}$. The means values were $0.71 \pm 0.69 \mathrm{mg} / \mathrm{L}$ in the Bandama river, $0.61 \pm 0.48$ $\mathrm{mg} / \mathrm{L}$ in the Kossou lake, $0.47 \pm 0.37 \mathrm{mg} / \mathrm{L}$ in the pond water and $5.65 \times 10^{-3} \pm 5.81 \times 10^{-4} \mathrm{mg} / \mathrm{L}$ in the groundwater. $\mathrm{Hg}$ total concentrations range was $1.01 \times 10^{-3}-0.97 \mathrm{mg} / \mathrm{L}$. The averages of total $\mathrm{Hg}$ were $0.06 \pm 0.04 \mathrm{mg} / \mathrm{L}, 0.62 \pm 0.8$ $\mathrm{mg} / \mathrm{L}, 0.33 \pm 0.46 \mathrm{mg} / \mathrm{L}$ and $1.33 \times 10^{-3} \pm 8.6 \times 10^{-4} \mathrm{mg} / \mathrm{L}$, in the Bandama river, the Kossou lake, the pond water and the groundwater, respectively. $\mathrm{Pb}$ concentrations varied between $5.4 \times 10^{-4}$ and $0.25 \mathrm{mg} / \mathrm{L}$. The averages $\mathrm{Pb}$ concentrations were $0.06 \pm 0.04 \mathrm{mg} / \mathrm{L}, 0.07 \pm 0.05 \mathrm{mg} / \mathrm{L}$, $0.1 \pm 0.09 \mathrm{mg} / \mathrm{L}$ and $7.34 \times 10^{-4} \pm 4.03 \times 10^{-4} \mathrm{mg} / \mathrm{L}$ in the Bandama river, the Kossou lake, the pond water and the groundwater, respectively.

In the surface waters, the averages of total $\mathrm{Ni}, \mathrm{Cd}, \mathrm{Hg}$, and $\mathrm{Pb}$ concentrations exceeded their guidelines values $(0.07 \mathrm{mg} / \mathrm{L}$ for $\mathrm{Ni}, 0.003 \mathrm{mg} / \mathrm{L}$ for $\mathrm{Cd}, 0.006 \mathrm{mg} / \mathrm{L}$ for $\mathrm{Hg}$, and $0.01 \mathrm{mg} / \mathrm{L}$ for $\mathrm{Pb}$ ) indicating water pollution by these trace metals. While, $\mathrm{Cr}$ and $\mathrm{Zn}$ average concentrations were below the limit of WHO $(0.05 \mathrm{mg} / \mathrm{L}$ for $\mathrm{Cr}$ and 3 $\mathrm{mg} / \mathrm{L}$ for $\mathrm{Zn}$ ). In the groundwater, the concentrations of $\mathrm{Ni}$, $\mathrm{Zn}, \mathrm{Pb}, \mathrm{Cd}, \mathrm{Cr}$, and $\mathrm{Hg}$ were lower than their WHO guidelines values. The results also showed that surface waters exhibited the most contaminated by $\mathrm{Ni}, \mathrm{Zn}, \mathrm{Pb}, \mathrm{Cd}$, $\mathrm{Cr}$, and $\mathrm{Hg}$ than groundwater. This is because average of total $\mathrm{Ni}, \mathrm{Zn}, \mathrm{Pb}, \mathrm{Cd}, \mathrm{Cr}$, and $\mathrm{Hg}$ concentrations in all surface waters were higher than their WHO guidelines values.

$\mathrm{Ni}, \mathrm{Zn}, \mathrm{Pb}, \mathrm{Cd}, \mathrm{Cr}$, and $\mathrm{Hg}$ spatial distribution trend in surface waters was as follow:

Ni: pond water $>$ Bandaman $>$ Kossou; Cr: pond water $>$ Bandaman $=$ Kossou; Cd: pond water $>$ Bandaman $>$ Kossou; Zn: Bandaman > Kossou > pond water; Hg: pond water > Kossou >Bandaman; $\mathrm{Pb}$ : pond water $>$ Kossou >Bandaman. $\mathrm{Ni}$ and $\mathrm{Cd}$ showed the same distribution trend, and, $\mathrm{Hg}$ and $\mathrm{Pb}$ showed the same distribution trend. The distribution patterns of $\mathrm{Zn}$ and $\mathrm{Cr}$ differed from those of $\mathrm{Ni}, \mathrm{Cd}, \mathrm{Hg}$ and $\mathrm{Pb}$. The same metals distribution trends could indicate the same sources of trace metals. Based on the total concentrations, trace metals $\mathrm{Ni}, \mathrm{Cd}, \mathrm{Hg}$, and $\mathrm{Pb}$ in surface waters might be derived from anthropogenic activities. While, $\mathrm{Zn}$ and $\mathrm{Cr}$ may be introduced in surface waters through natural processes. Trace metals $(\mathrm{Ni}, \mathrm{Pb}, \mathrm{Cd}$, and $\mathrm{Hg}$ ) in surface waters may be due to the discharge from urban, agricultural and mining wastes. For example, during gold production, mercury was used to amalgamate and concentrate the gold [14]. After the washing process, the mercury was released into the water. In addition, the study area is dominated by agricultural activities. Therefore, $\mathrm{Ni}$, $\mathrm{Cd}, \mathrm{Hg}$, and $\mathrm{Pb}$ in the pond water, the Bandama river and the Kossou lake may also derive from the use of pesticides and fertilizers as mentioned by Lü et al [62] and by Ouattara et $a l$ [36]. Lü et $a l$ [62] and Luo et al [63] have reported that vehicular exhausts from leaded gasoline are a source of $\mathrm{Pb}$ in the environment. In the study area vehiculars were used by the miners to collect water for the washing process. Therefore, the use of these vehicles may also explain the high concentrations of $\mathrm{Pb}$. The low concentrations of all trace metals in groundwater may be explained by natural process. [11,64].

For comparison purposes, the trace metals concentrations in this study and in some other mining areas are summarized in Table 5. Trace metals $(\mathrm{Ni}, \mathrm{Pb}, \mathrm{Cd}$, $\mathrm{Cr}$, and $\mathrm{Hg}$ ) concentrations obtained in surface waters around Bouafle mining areas were higher than those reported in surface waters from Ceraína, Brazil [21], Anka, Nigeria [28], Smalong river, China [3], Suárez Cauca, Colombia [20]. However, Zn concentrations were lower than those from Sambo, South Korea [22] and Tributary, China [3]. In groundwater, trace metals concentrations were lower than those from Singhbhum, India [65], Tongon (except Cd), Côte d'Ivoire [35], Buddeun, South Korea [22], SW Ashanti, Ghana [32]. However, the averages concentrations of $\mathrm{Cd}$ and $\mathrm{Zn}$ in groundwater were higher than those from Samalong, China [3] and Tongon, Côte d'Ivoire [35], respectively.

Table 5. Trace metals concentrations in this study and in some other mining areas.

\begin{tabular}{lllll}
\hline Sample & & Country & $\mathbf{N i}(\boldsymbol{\mu g} / \mathbf{L})$ & $\mathbf{C r}(\boldsymbol{\mu g} / \mathbf{L})$ \\
\hline Surface water & Bandama River & Côte d'Ivoire & $1471.2 \pm 447.0$ & $22.5 \pm 18.3$ \\
& Kossou lake & Côte d'Ivoire & $1220.0 \pm 294.5$ & $22.5 \pm 31.4$ \\
& Pond water & Côte d'Ivoire & $2360 \pm 1088$ & $27.7 \pm 34.3$ \\
& Tongon & Côte d'Ivoire & & $6 \pm 1.7 \pm 32.9$ \\
& Smalong River & China & & $5.3 \pm 30.6$ \\
& & & & $208.0 \pm 145.6$ \\
\end{tabular}




\begin{tabular}{|c|c|c|c|c|c|}
\hline Sample & & Country & $\mathrm{Ni}(\mu \mathrm{g} / \mathrm{L})$ & $\mathrm{Cr}(\mu \mathrm{g} / \mathrm{L})$ & $\mathrm{Cd}(\mu \mathrm{g} / \mathrm{L})$ \\
\hline \multirow{13}{*}{ Groundwater } & Tributary River & China & \multirow{3}{*}{$2.1 \pm 0.5$} & $2.8 \pm 1.1$ & $1.04 \pm 0.04$ \\
\hline & Ceraíma & Brazil & & \multirow{2}{*}{$2.2 \pm 0.4$} & $1.3 \pm 0.2$ \\
\hline & Suárez Cauca & Colombia & & & \\
\hline & Sambo & South Korea & \multirow{4}{*}{$0.02 \pm 0.0001$} & \multirow{4}{*}{$0.02 \pm 0.0001$} & $14.0 \pm 4.2$ \\
\hline & Anka & Nigeria & & & $0.006 \pm 0.01$ \\
\hline & Ankobra & Ghana & & & $0-0.004$ \\
\hline & Manyera & Nigeria & & & \\
\hline & Bouafle & Côte d'Ivoire & \multirow[t]{2}{*}{$4.71 \pm 1.43$} & $1.83 \pm 0.56$ & $0.98 \pm 0.32$ \\
\hline & Tongon & Côte d'Ivoire & & $17 \pm 17-40 \pm 77$ & $0.01 \pm 0.01-0.19 \pm 0.54$ \\
\hline & Samalong & China & \multirow[t]{2}{*}{ - } & \multirow[t]{2}{*}{$3.76 \pm 1.61$} & - \\
\hline & Buddeun & South Korea & & & $170.2 \pm 142.2$ \\
\hline & Singhbhum & India & \multirow[t]{2}{*}{$50 \pm 30$} & \multirow[t]{2}{*}{$150 \pm 50$} & $20 \pm 20$ \\
\hline & SW Ashanti & Ghana & & & \\
\hline
\end{tabular}

Table 5. Continued.

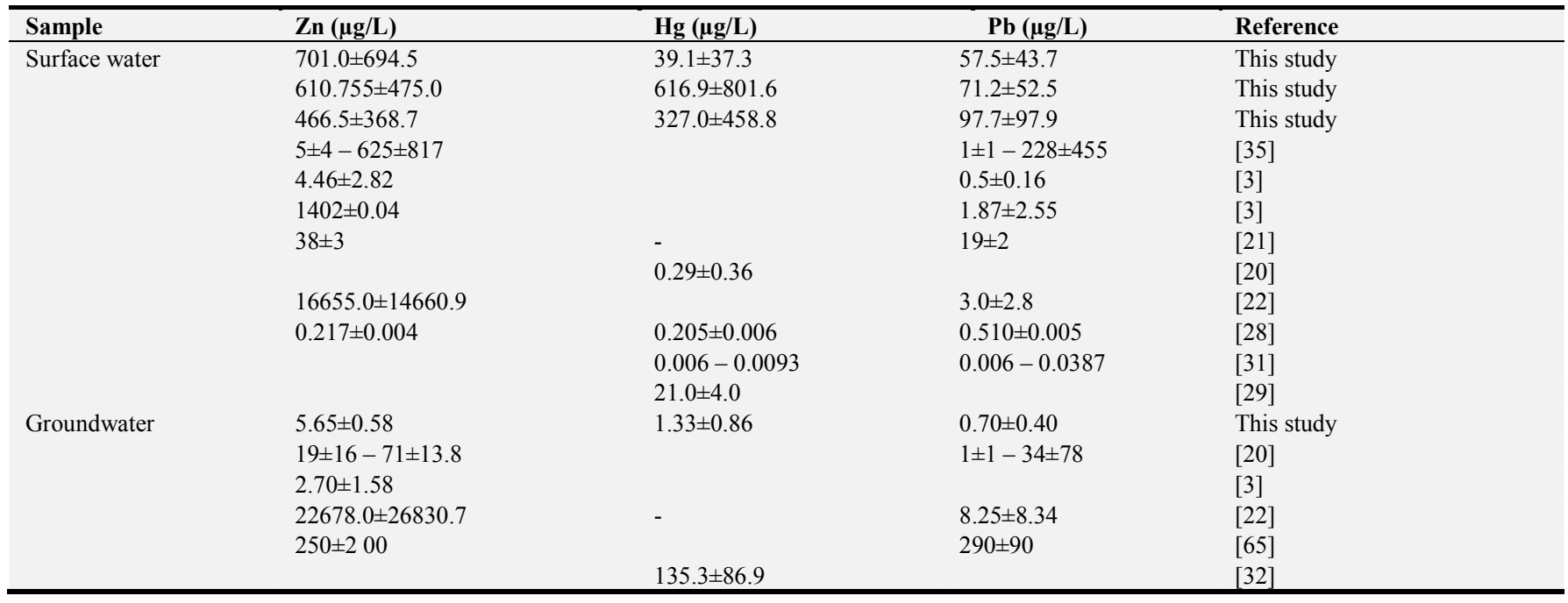

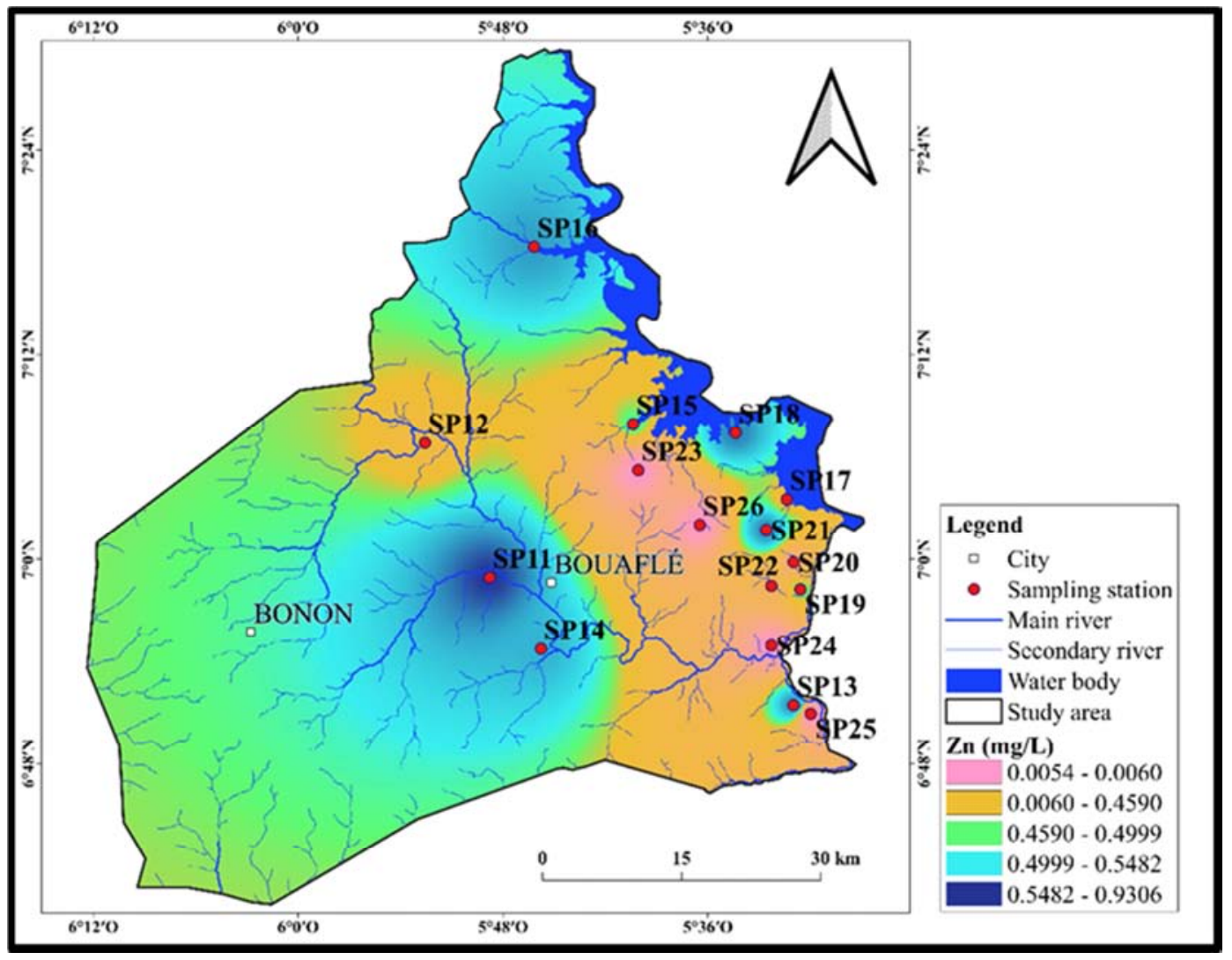



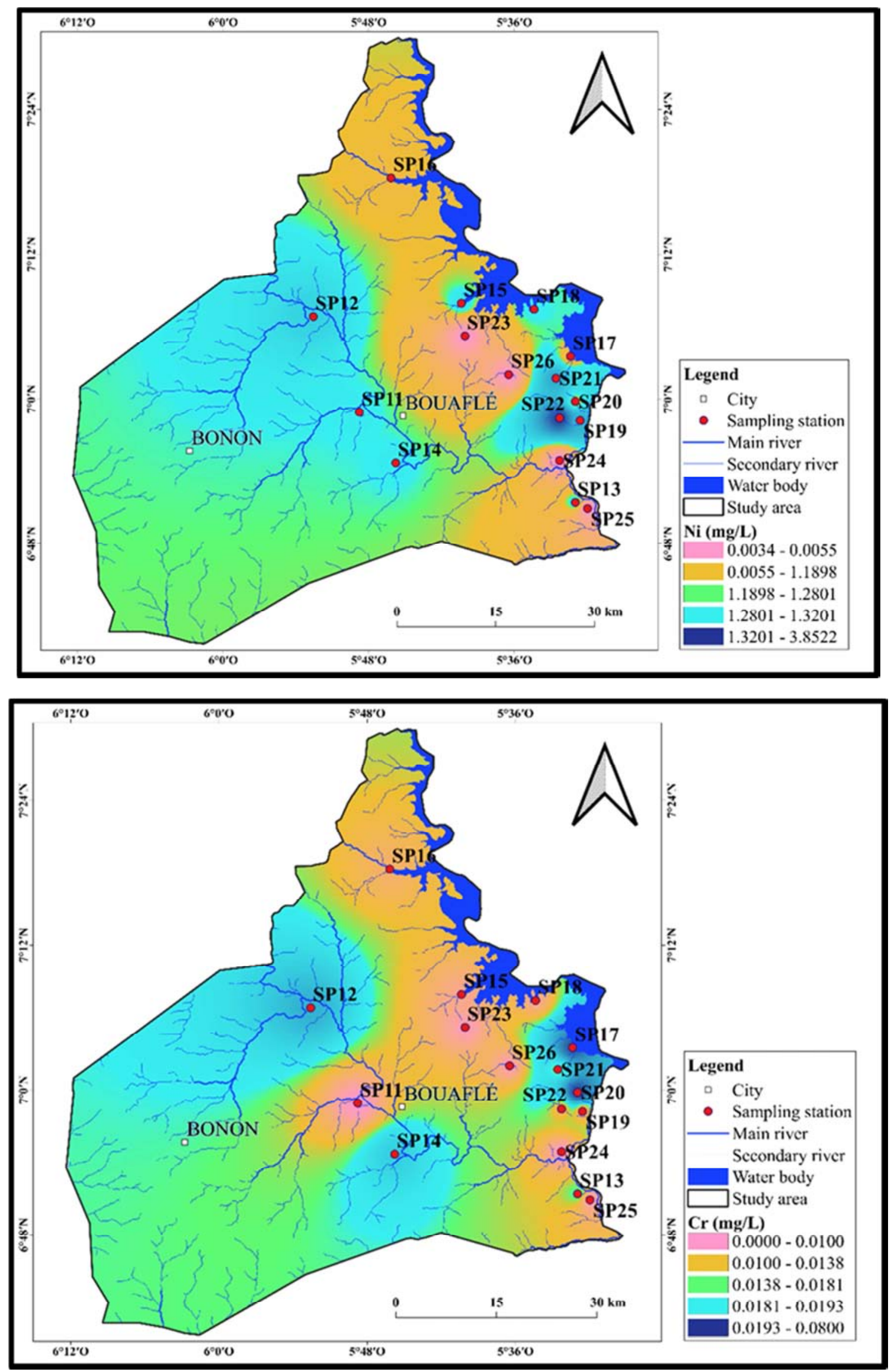

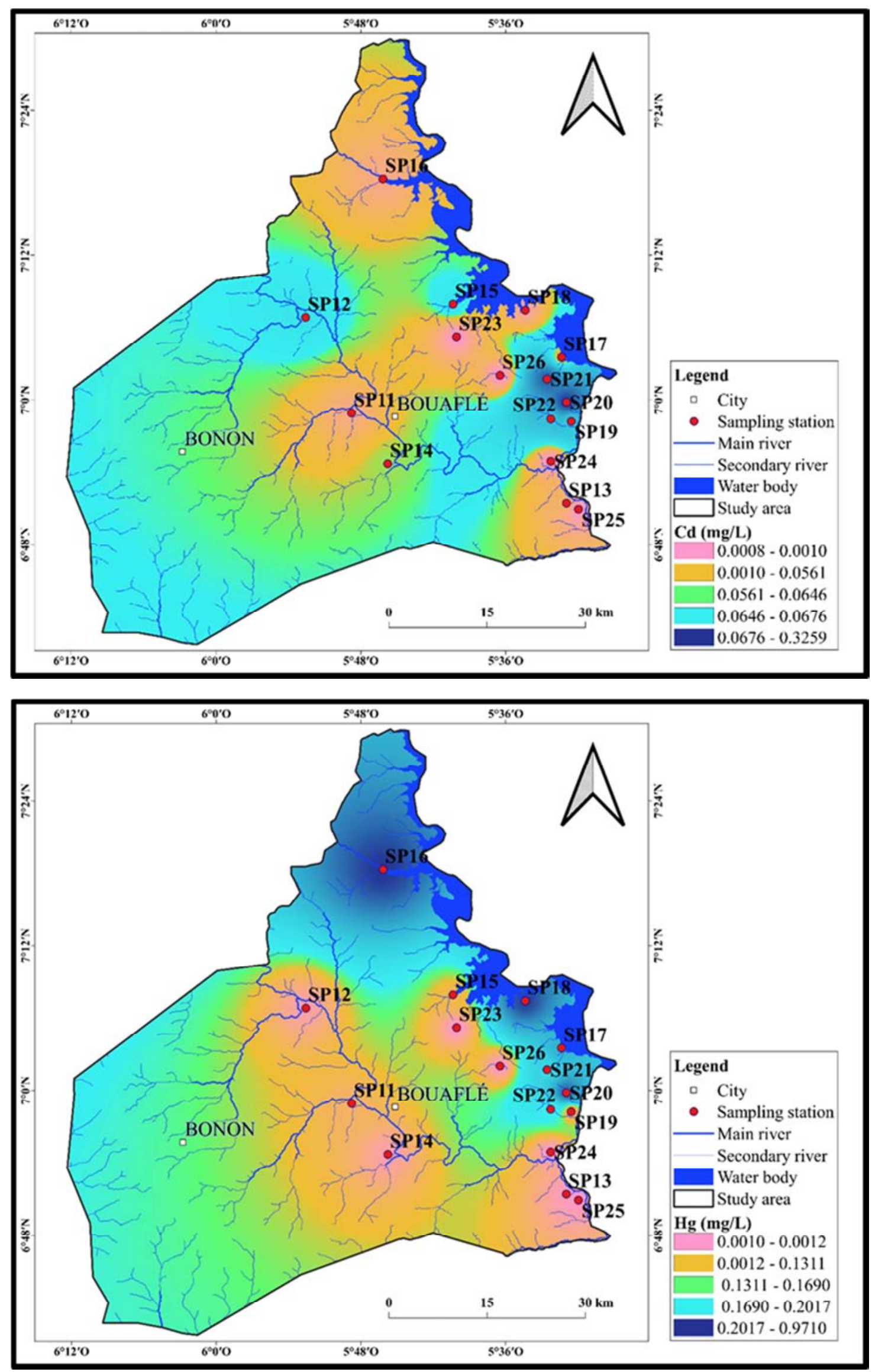


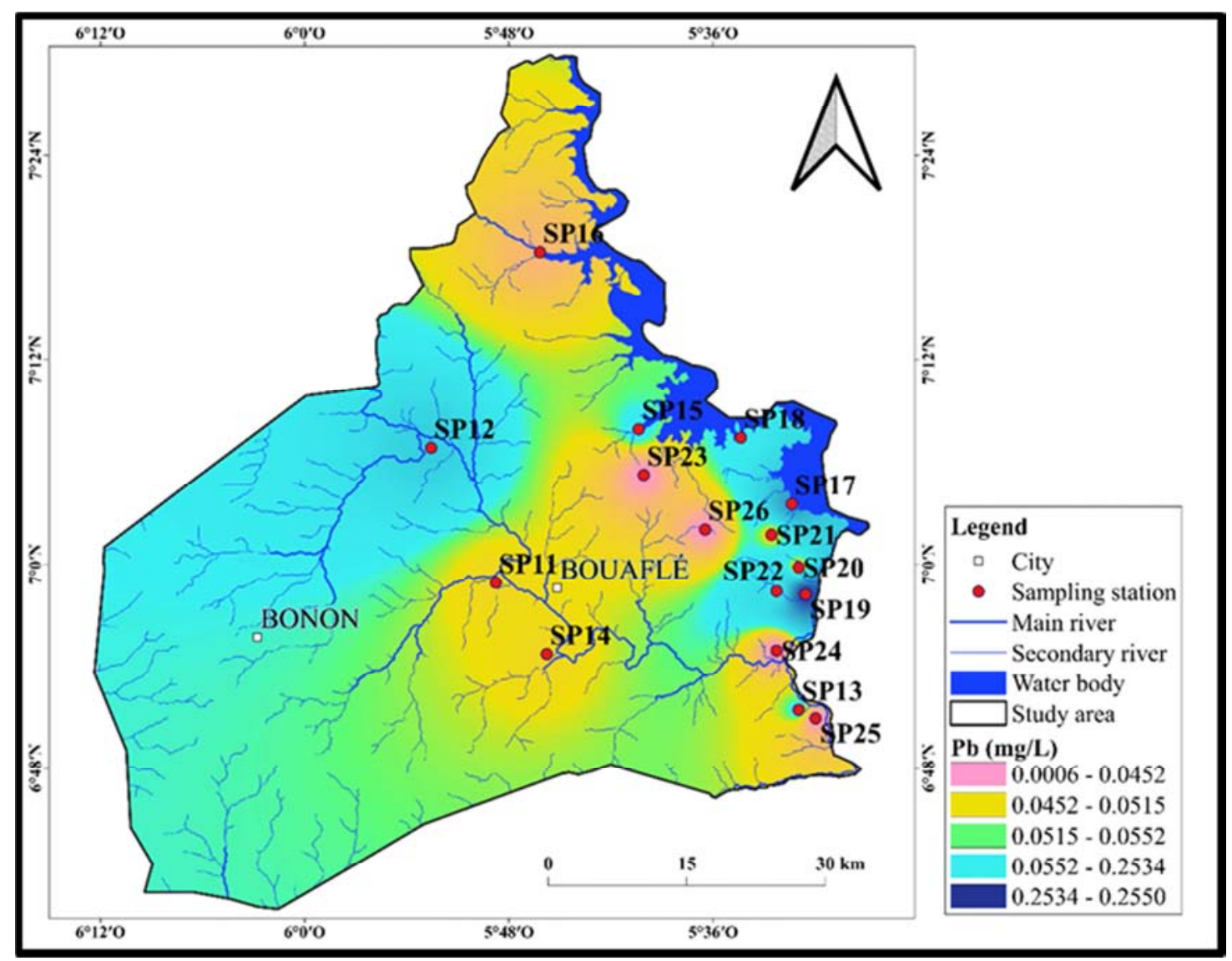

Figure 2. Distribution patterns of $\mathrm{Zn}, \mathrm{Ni}, \mathrm{Cr}, \mathrm{Cd}, \mathrm{Hg}$, and $\mathrm{Pb}$ in surface waters and groundwater.

\subsection{Pollution Indices and Water Quality Assessment}

The pollution indices HPI and HEI values are shown in Table 6. Based on HPI scale, HPI mean values $(1796.39 \pm 1258.04 \leq$ HPI $\leq 20086.88 \pm 25433.87)$ obtained in surface waters showed that all waters samples were unsuitable for consumption. While, groundwater represented low pollution of heavy metal $(\mathrm{HPI}=50.12 \pm 12.86)$. The mean values of HEI varied between $149.30 \pm 65.99$ and $431.34 \pm 405.43$ in surface water, indicating high pollution of trace metals in surface waters (HEI $>20)$. In groundwater, the HEI mean value $(1.75 \pm 0.77)$ was lower than 10 showing low pollution of trace metals.

The results of water quality index WQI are reported in Table 5. The WQI mean values of surface waters varied between $372.09 \pm 91.54$ and $1487.28 \pm 800.85$. In groundwater, the mean values of WQI were $17.88 \pm 1.37$. These results showed that groundwater quality is excellent. While, all surface waters are undrinkable.

The high pollution level of surface waters may be due to mining wastes and waste residues from agricultural activities discharge in the surface waters. Therefore, environmental management and reduced surface waters pollution by trace metals are highly crucial.

Table 6. Averages values of WQI, HPI, and HEI..

\begin{tabular}{llll}
\hline & WQI & HPI & HEI \\
\hline Bandama & $372.09 \pm 91.54$ & $1796.39 \pm 1258.04$ & $149.30 \pm 65.99$ \\
Kossou & $1325.12 \pm 590.19$ & $20086.88 \pm 25433.87$ & $431.34 \pm 405.43$ \\
Pond Water & $1487.28 \pm 800.85$ & $12532.65 \pm 14590.87$ & $416.65 \pm 182.69$ \\
Groundwater & $17.88 \pm 1.37$ & $50.12 \pm 12.86$ & $1.75 \pm 0.77$ \\
\hline
\end{tabular}

\subsection{Assessment of Human Health Risk}

\subsubsection{Non-carcinogenic Risk}

The averages of $\mathrm{HQ}_{\text {der, }}, \mathrm{HQ}_{\text {ing }}$, and $\mathrm{HI}$ were reported in Table 7. The results showed that for groundwater, the $\mathrm{HQ}_{\mathrm{der}}$, $\mathrm{HQ}_{\text {ing }}$ and $\mathrm{HI}$ values were below 1 for all trace metals, showing low adverse effects.

Trace metals $\mathrm{Zn}$ and $\mathrm{Cr}$ did not cause any adverse effects in surface waters (HQder, HQing, and HI values were less than one). $\mathrm{Ni}, \mathrm{Hg}, \mathrm{Cd}$ and $\mathrm{Pb} \mathrm{HQ}_{\text {ing }}$ and $\mathrm{HI}$ mean values in all the surface waters varied between $1.505 \pm 1.144$ and $80.507 \pm 104.615$. Therefore, adverse effects can occur on human health through the ingestion of $\mathrm{Ni}, \mathrm{Hg}, \mathrm{Cd}$, and $\mathrm{Pb}$. While, $\mathrm{HQ}_{\mathrm{der}}$ mean values for $\mathrm{Ni}$ and $\mathrm{Pb}$ were lower than 1 (varying between $0.009 \pm 0.003$ and $0.04 \pm 0.041$ ), showing low adverse effects through dermal contact. In addition, 
potential adverse effects can occur through $\mathrm{Hg}$ by dermal contact with the waters of the Kossou Lake $\left(\mathrm{HQ}_{\mathrm{der}}=\right.$ $5.116 \pm 6.642)$ and of the pond water $\left(\mathrm{HQ}_{\mathrm{der}}=2.709 \pm 3.802\right)$. While, for the Bandama river no effects can be caused. Indeed, the $\mathrm{HQ}_{\text {der }}$ average was $0.324 \pm 0.309$. $\mathrm{Cd}$ concentration in the pond waters can cause adverse effects by dermal contact due to the $\mathrm{HQ}_{\text {der }}$ average of $1.447 \pm 1.013$. Surface waters around Bouafle mining areas can cause potential adverse effects related to metals through ingestion due to $H Q_{\text {ing }}$ higher than $H Q_{\text {der }}$.

Table 7. Calculated $H Q_{d e r} H Q_{i n g}$ and $H I$ with trace metals..

\begin{tabular}{|c|c|c|c|c|c|}
\hline & & Bandama & Kossou & Pond water & Groundwater \\
\hline \multirow{3}{*}{$\mathrm{Ni}$} & $\mathrm{HQ}_{\text {ing }}$ & $2.697 \pm 0.819$ & $2.236 \pm 0.539$ & $4.326 \pm 1.994$ & $0.008 \pm 0.003$ \\
\hline & $\mathrm{HQ}_{\text {der }}$ & $0.009 \pm 0.003$ & $0.008 \pm 0.002$ & $0.015 \pm 0.007$ & $3.03 \times 10^{-5} \pm 9.2 \times 10^{-6}$ \\
\hline & HI & $2.707 \pm 0.822$ & $2.244 \pm 0.542$ & $4.342 \pm 2.001$ & $0.008 \pm 0.003$ \\
\hline \multirow{3}{*}{$\mathrm{Cr}$} & $\mathrm{HQ}_{\text {ing }}$ & $0.275 \pm 0.224$ & $0.275 \pm 0.224$ & $0.339 \pm 0.419$ & $0.022 \pm 0.007$ \\
\hline & $\mathrm{HQ}_{\text {der }}$ & $0.104 \pm 0.085$ & $0.104 \pm 0.085$ & $0.128 \pm 0.159$ & $0.008 \pm 0.002$ \\
\hline & $\mathrm{HI}$ & $0.379 \pm 0.309$ & $0.379 \pm 0.530$ & $0.468 \pm 0.579$ & $0.031 \pm 0.009$ \\
\hline \multirow{3}{*}{$\mathrm{Cd}$} & $\mathrm{HQ}_{\text {ing }}$ & $3.795 \pm 2.414$ & $3.043 \pm 2.241$ & $15.253 \pm 10.680$ & $0,071 \pm 0.024$ \\
\hline & $\mathrm{HQ}_{\text {der }}$ & $0.360 \pm 0.229$ & $0.288 \pm 0.212$ & $1.447 \pm 1.013$ & $0.007 \pm 0.002$ \\
\hline & HI & $4.155 \pm 2.644$ & $3.332 \pm 2.455$ & $16.701 \pm 11.694$ & $0.078 \pm 0.026$ \\
\hline \multirow{3}{*}{$\mathrm{Zn}$} & $\mathrm{HQ}_{\text {ing }}$ & $0.085 \pm 0.084$ & $0.074 \pm 0.058$ & $0.057 \pm 0.045$ & $6.9 \times 10^{-4} \pm 7.1 \times 10^{-5}$ \\
\hline & $\mathrm{HQ}_{\text {der }}$ & $0.012 \pm 0.012$ & $0.011 \pm 0.008$ & $0.008 \pm 0.006$ & $9.84 \times 10^{-5 \pm} 1.01 \times 10^{-5}$ \\
\hline & HI & $0.097 \pm 0.096$ & $0.085 \pm 0.066$ & $0.065 \pm 0.051$ & $7.9 \times 10^{-4} \pm 8.1 \times 10^{-5}$ \\
\hline \multirow{3}{*}{$\mathrm{Hg}$} & $\mathrm{HQ}_{\text {ing }}$ & $4.781 \pm 4.569$ & $75.396 \pm 97.973$ & $39.966 \pm 56.081$ & $2.560 \pm 0.105$ \\
\hline & $\mathrm{HQ}_{\text {der }}$ & $0.324 \pm 0.309$ & $5.116 \pm 6.642$ & $2.709 \pm 3.802$ & $0.040 \pm 0.007$ \\
\hline & $\mathrm{HI}$ & $5.106 \pm 4.879$ & $80.507 \pm 104.615$ & $42.676 \pm 59.882$ & $0.173 \pm 0.112$ \\
\hline \multirow{3}{*}{$\mathrm{Pb}$} & $\mathrm{HQ}_{\text {ing }}$ & $1.505 \pm 1.144$ & $1.866 \pm 1.375$ & $2.560 \pm 2.566$ & $0.019 \pm 0.010$ \\
\hline & $\mathrm{HQ}_{\text {der }}$ & $0.024 \pm 0.018$ & $0.029 \pm 0.021$ & $0.040 \pm 0.041$ & $3 \times 10^{-4} \pm 1.7 \times 10^{-4}$ \\
\hline & HI & $1.529 \pm 1.162$ & $1.895 \pm 1.396$ & $2.601 \pm 2.607$ & $0.019 \pm 0.011$ \\
\hline
\end{tabular}

\subsubsection{Carcinogenic Risk}

Trace metals $\mathrm{Pb}, \mathrm{Cr}, \mathrm{Ni}$ and $\mathrm{Cd}$ are recognized as carcinogens for human [66]. Therefore, the carcinogenic risk was assessed using these trace metals. The values of $\mathrm{CR}_{\text {ing, }}$, $\mathrm{CR}_{\mathrm{der}}$ and total risk $(\mathrm{CR})$ are reported in Table 8.

Dermal contact of groundwater would have no carcinogenic effect due to all trace metals as, the dermal carcinogenic risk values of $\mathrm{Cd}, \mathrm{Cr}$ and $\mathrm{Ni}$ were below $10^{-6}$ $\left(8.2 \times 10^{-9} \leq \mathrm{CR}_{\mathrm{der}} \leq 7.5 \times 10^{-8}\right)$ and those of $\mathrm{Pb}\left(3.1 \times 10^{-6} \leq\right.$ $\left.\mathrm{CR}_{\mathrm{der}} \leq 1 \times 10^{-5}\right)$ were within the tolerable range $\left(10^{-6}-10^{-4}\right)$. With surface waters, dermal contact would pose great risk due to $\mathrm{Pb}\left(6.1 \times 10^{-4} \leq \mathrm{CR}_{\mathrm{der}} \leq 0.002\right)$, while no significant risk $\left(2.08 \times 10^{-8} \leq \mathrm{CR}_{\mathrm{der}} \leq 1.1 \times 10^{-5}\right)$ would be pose due to $\mathrm{Ni}, \mathrm{Cd}$ and $\mathrm{Cr}$.

The $\mathrm{CR}_{\text {ing }}$ values of $\mathrm{Ni}, \mathrm{Cr}, \mathrm{Cd}, \mathrm{Zn}, \mathrm{Hg}$, and $\mathrm{Pb}$ for the surface waters exceeded $10^{-4}\left(8.7 \times 10^{-4} \leq \mathrm{CR}_{\text {ing }} \leq 1.165\right)$, indicating potentially great carcinogenic effects. In groundwater $\mathrm{CR}_{\text {ing }}$ average for $\mathrm{Cd}$ was $9.3 \times 10^{-5 \pm} 3.3 \times 10^{-5}$. The $\mathrm{CR}_{\text {ing }}$ averages of $\mathrm{Ni}, \mathrm{Cr}$ and $\mathrm{Pb}$ in groundwater were $2 \times 10^{-4 \pm} 5.8 \times 10^{-5}, \quad 1.6 \times 10^{-4 \pm} 5.2 \times 10^{-5}$ and $0.003 \pm 0.002$, respectively, indicating possible great carcinogenic effects through ingestion.

The total carcinogenic risk (CR) values of $\mathrm{Ni}, \mathrm{Pb}, \mathrm{Cd}$, and $\mathrm{Cr}$ for the surface waters ranged between $0.002 \pm 0.001$ and $0.422 \pm 0.423$. In groundwater, the $\mathrm{CR}$ averages of $\mathrm{Ni}, \mathrm{Pb}$ and Cr varied between $1.6 \times 10^{-4 \pm} 5.2 \times 10^{-5}$ and $0.003 \pm 0.002$. These results showed that possible carcinogenic effects can occur. In this study, $\mathrm{CR}_{\text {ing }}$ averages were higher than those of $\mathrm{CR}_{\mathrm{der}}$. Therefore, it can be inferred that the population around the artisanal gold mining areas in Bouafle could develop cancer related to $\mathrm{Ni}, \mathrm{Pb}$, and $\mathrm{Cr}$ through waters ingestion. It is therefore important to treat waters for removing trace metals before using them for irrigation and domestic purposes.

Table 8. Calculated carcinogenic risk through ingestion $\left(C R_{\text {ing }}\right)$ and dermal contact $\left(C R_{\text {der) }}\right.$, and total carcinogenic risk $(C R)$ with trace metals.

\begin{tabular}{clllll}
\hline & & Bandama & Kossou & Pond water & Groundwater \\
\hline \multirow{3}{*}{$\mathrm{Ni}$} & $\mathrm{CR}_{\text {ing }}$ & $0.059 \pm 0.018$ & $0.049 \pm 0.012$ & $0.095 \pm 0.044$ & $2 \times 10^{-4 \pm} 5.8 \times 10^{-5}$ \\
& $\mathrm{CR}_{\text {der }}$ & $1.5 \times 10^{-5 \pm} 4.6 \times 10^{-5}$ & $1.2 \times 10^{-5 \pm} 3 \times 10^{-6}$ & $2.4 \times 10^{-5 \pm} 1.1 \times 10^{-5}$ & $4.7 \times 10^{-8 \pm} 1.5 \times 10^{-8}$ \\
& $\mathrm{CR}$ & $0.059 \pm 0.018$ & $0.049 \pm 0.012$ & $0.095 \pm 0.044$ & $1.8 \times 10^{-4 \pm} 5.8 \times 10^{-5}$ \\
$\mathrm{Cr}$ & $\mathrm{CR}_{\text {ing }}$ & $0.002 \pm 0.001$ & $0.002 \pm 0.003$ & $0.002 \pm 0.003$ & $1.6 \times 10^{-4 \pm} 5.2 \times 10^{-5}$ \\
& $\mathrm{CR}_{\text {der }}$ & $4.6 \times 10^{-7 \pm} 3.8 \times 10^{-7}$ & $4.6 \times 10^{-7 \pm} 6.5 \times 10^{-6}$ & $5.7 \times 10^{-7 \pm} 7.1 \times 10^{-7}$ & $3.7 \times 10^{-8 \pm} 1.2 \times 10^{-8}$ \\
& $\mathrm{CR}$ & $0.002 \pm 0.001$ & $0.002 \pm 0.003$ & $0.002 \pm 0.003$ & $1.6 \times 10^{-4 \pm} 5.2 \times 10^{-5}$ \\
$\mathrm{Cd}$ & $\mathrm{CR}_{\text {ing }}$ & $0.005 \pm 0.003$ & $0.004 \pm 0.003$ & $0.020 \pm 0.014$ & $9.3 \times 10^{-5 \pm} 3.3 \times 10^{-5}$ \\
& $\mathrm{CR}_{\text {der }}$ & $1.2 \times 10^{-6 \pm} 7.5 \times 10^{-7}$ & $9.5 \times 10^{-7 \pm} 6.9 \times 10^{-7}$ & $4.7 \times 10^{-6 \pm} 3.3 \times 10^{-6}$ & $2.2 \times 10^{-8 \pm} 7.9 \times 10^{-9}$ \\
& $\mathrm{CR}$ & $0.005 \pm 0.003$ & $0.004 \pm 0.003$ & $0.020 \pm 0.014$ & $9.3 \times 10^{-5 \pm} 3.3 \times 10^{-5}$ \\
$\mathrm{~Pb}$ & $\mathrm{CR}_{\text {ing }}$ & $0.248 \pm 0.188$ & $0.307 \pm 0.226$ & $0.422 \pm 0.422$ & $0.003 \pm 0.002$ \\
& $\mathrm{CR}_{\text {der }}$ & $3.5 \times 10^{-4 \pm} 2.6 \times 10^{-4}$ & $4.3 \times 10^{-4 \pm} 3.2 \times 10^{-4}$ & $6 \times 10^{-4 \pm} 6 \times 10^{-4}$ & $4.7 \times 10^{-6 \pm} 2.6 \times 10^{-6}$ \\
& $\mathrm{CR}$ & $0.248 \pm 0.188$ & $0.307 \pm 0.226$ & $0.422 \pm 0.423$ & $0.003 \pm 0.002$ \\
\hline
\end{tabular}




\section{Conclusion}

Trace metals (Ni, Cr, Zn, Cd, $\mathrm{Hg}$ and $\mathrm{Pb}$ ) distribution and human health risk assessment in surface waters and groundwater around artisanal gold mining areas in the central western of Côte d'Ivoire were investigated. The results showed that $\mathrm{Ni}, \mathrm{Cd}, \mathrm{Pb}$, and $\mathrm{Hg}$ concentrations in groundwater were below the WHO guidelines. While in the surface waters, the averages of total $\mathrm{Ni}, \mathrm{Cd}, \mathrm{Hg}$, and $\mathrm{Pb}$ concentrations exceeded their WHO guidelines values. The spatial maps of trace metals indicated same distribution trend for $\mathrm{Ni}$ and $\mathrm{Cd}$, and for $\mathrm{Hg}$ and $\mathrm{Pb}$, while those of $\mathrm{Zn}$ and $\mathrm{Cr}$ differed from those of $\mathrm{Ni}, \mathrm{Cd}, \mathrm{Hg}$ and $\mathrm{Pb}$. The pollution indices HPI and HEI indicated low and high pollution of groundwater and surface waters, respectively. In addition, the WQI index indicated that groundwater quality was excellent. While, all surface waters were undrinkable. The results of non-carcinogenic risk showed that for groundwater, the $\mathrm{HQ}_{\mathrm{der}}$, $\mathrm{HQ}_{\text {ing }}$ and $\mathrm{HI}$ values were below 1 for all trace metals, showing low adverse effects. With the surface waters, trace metals $\mathrm{Zn}$ and $\mathrm{Cr}$ did not cause any threats to human health. The ingestion hazard quotient $\left(\mathrm{HQ}_{\text {ing }}\right)$ and total index $(\mathrm{HI})$ of $\mathrm{Cd}, \mathrm{Ni}, \mathrm{Hg}$, and $\mathrm{Pb}$ exceeded 1 in surface waters, showing adverse effects on humans. Total carcinogenic (CR) of Cd for surface waters showed potential great carcinogenic effects. In contrast, with groundwater, humans are not exposed to cancer effects related to $\mathrm{Cd}$. The total carcinogenic risks (CR) of $\mathrm{Cr}, \mathrm{Pb}$, and $\mathrm{Ni}$ for surface waters and groundwater exceeded $10^{-4}$, indicating a possible carcinogenic effect on human health. It is therefore important to treat waters for removing trace metals before using them for irrigation and domestic purposes. Complementary studies including $\mathrm{Ni}, \mathrm{Zn}$, $\mathrm{Cd}, \mathrm{Hg}, \mathrm{Cr}$, and $\mathrm{Pb}$ accumulation in the blood, urine, and hair of residents should be investigated to better understand the risks related to $\mathrm{Ni}, \mathrm{Zn}, \mathrm{Cd}, \mathrm{Hg}, \mathrm{Cr}$, and $\mathrm{Pb}$.

\section{Conflict to Interest}

The authors declare no competing interests.

\section{Acknowledgements}

The authors want to thank the authorities of Bouafle town and the Director of Felix Houphouët-Boigny National Polytechnic Institute, Yamoussoukro for their encouragement and support.

\section{References}

[1] Long, X., Liu, F., Zhou, X., Pi, J., Yin, W., Li, F., Huang, S. (2021). Estimation of spatial distribution and health risk by arsenic and heavy metals in shallow groundwater around Dongting Lake plain using GIS mapping. Chemosphere 269: 1-11. https://doi.org/10.1016/j.chemosphere.2020.128698

[2] Taiwo, A. M., Awomeso, J. A. (2017). Assessment of trace metal concentration and health risk of artisanal gold mining activities in Ijeshaland, Osun State Nigeria- Part 1. Journal of Geochemical Exploration 177: 1-10. https://doi.org/10.1016/j.gexplo.2017.01.009

[3] Qiao, D., Wang, G., Li, X., Wang, S., Zhao, Y. (2020). Pollution, sources and environmental risk assessment of heavy metals in the surface AMD water, sediments and surface soils around unexploited Rona $\mathrm{Cu}$ deposit, Tibet, China. Chemosphere 248: 1-42. https://doi.org/10.1016/j.chemosphere.2020.125988

[4] Wang, Y., Donga, R., Zhou, Y., Luo, X. (2019). Characteristics of groundwater discharge to river and related heavy metal transportation in a mountain mining area of Dabaoshan, Southern China. Sciences of the Total Environment 679: 346-358. https://doi.org/10.1016/j.scitotenv.2019.04.273

[5] Cai, L. M., Xu, Z. C., Qi, J. Y., Feng, Z. Z., Xiang, T. S. (2015). Assessment of exposure to heavy metals and health risks among residents near Tonglushan mine in Hubei, China. Chemosphere 127: 127-135. https://doi.org/10.1016/j.chemosphere.2015.01.027.

[6] Fonseca, A. R., Sanches-Fernandes, L. F., FontainhasFernandes, A., Monteiro, S. M., Pacheco, F. A. L. (2017). The impact of freshwater metal concentrations on the severity of histopathological changes in fish gills: a statistical perspective. Sciences of the Total Environment 599-600: 217-226. https://doi.org/10.1016/j.scitotenv.2017.04.196

[7] Kouassi, N. G. L., Yao, K. M., Sangare, N., Trokourey, A., Metongo, B. S. (2019). The mobility of the trace metals copper, zinc, lead, cobalt, and nickel in tropical estuarine sediments, Ebrie Lagoon, Côte d'Ivoire. Journal of Soils and Sediments 19: 929-944. https://doi.org/10.1007/s11368-0182062-8

[8] Soumahoro, N. S., Kouassi, N. L. B., Yao, K. M., Kwa-Koffi, E. K., Kouassi, A. M., Trokourey, A. (2021). Impact of municipal solid waste dumpsites on trace metal contamination levels in the surrounding area: a case study in West Africa, Abidjan, Cote d'Ivoire. Environmental Science and Pollution Research 28: 30425-30435. https://doi.org/10.1007/s11356021-13987-3

[9] Zhu, X., Fan, Y., Sheng, J., Gu, L., Tao, Q., Huang, R., Liu, K., Yang, L., Chen, G., Cao, H., Li, K., Tao, F., Wang, S. (2021). Association Between Blood Heavy Metal Concentrations and Dyslipidemia in the Elderly. Biological Trace Element Research 199: 1280-1290. https://doi.org/10.1007/s12011-020-02270-0

[10] Bhateria, R., Singh, R. (2019). A review on nanotechnological application of magnetic iron oxides for heavy metal removal. Journal of Water Process Engineering 31: 1-10. https://doi.org/10.1016/j.jwpe.2019.100845

[11] Shil, S., Singh, U.K. (2019). Health risk assessment and spatial variations of dissolved heavy metals and metalloids in a tropical river basin system. Ecological Indicator 106: 1-12. https://doi.org/10.1016/j.ecolind.2019.105455

[12] Myong, J. P., Kim, H. R., Jang, T. W., Lee, H. E., Koo, J. W. (2014). Association between blood cadmium levels and 10year coronary heart disease risk in the general Korean population: the Korean National Health and nutrition examination survey 2008-2010. PLoS One 9: 1-9. https://doi.org/10.1371/journal.pone.0111909 
[13] Sifou, A., Benabbou, A., Aakame, R. B., Mahnine, N., Antonopoulo, A., Halim, M., Zinedine, A. (2021). Trace Elements in Breakfast Cereals and Exposure Assessment in Moroccan Population: Case of Lead and Cadmium. Biological Trace Element Research 199: 1268-1275. https://doi.org/10.1007/s12011-020-02265-x

[14] Mantey, J., Nyarko, K. B., Owusu-Nimo, F., Awua, K. A., Bempah, C. K., Amankwah, R. K., Akatu, W. E., AppiahEffah, E. (2020). Mercury contamination of soil and water media from different illegal artisanal small-scale gold mining operations (galamsey). Heliyon 6: 4312-4325. https://doi.org/10.1016/j.heliyon.2020.e04312

[15] Andreoli, V., Sprovieri, F. (2017). Genetic Aspects of Susceptibility to Mercury Toxicity: An Overview. International Journal of Environmental Research and Public Health 14: 1-25. https://doi.org/10.3390/ijerph14010093

[16] Safdar, L. B., Almas, F., Rehman, A., Umer, M. J., Shah, S. M. A., Uddin, S., Ashfaq, S., Rahman, H. U., Umar, M. Q. (2020) Genetic dissection of Ni toxicity in a spring wheat diversity panel by using $90 \mathrm{~K} \mathrm{SNP}$ array. Current Plant Biology 24: 100175-100182. https://doi.org/10.1016/j.cpb.2020.100175

[17] Kunter, I., Hürer, N., Gülcan, H. O., Öztürk, B., Doğan, I., Şahin, G., (2017) Assessment of Aflatoxin M1 and Heavy Metal Levels in Mothers Breast Milk in Famagusta, Cyprus. Biological Trace Element Research 175: 42-49. https://doi.org/10.1007/s12011-016-0750-z

[18] Lin, W., Wu, K., Lao, Z., Hu, W., Lin, B., Li, Y., Fan, H., Hu, J. (2019). Assessment of trace metal contamination and ecological risk in the forest ecosystem of dexing mining area in northeast Jiangxi Province, China. Ecotoxicology and $\begin{array}{llll}\text { Environmental } & \text { Safety } & \text { 167: }\end{array}$ https://doi.org/10.1016/j.ecoenv.2018.10.001

[19] Torrance, K. W., Redwood, S. D., Cecchi, A. (2021). The impact of artisanal gold mining, ore processing and mineralization on water quality in Marmato, Colombia. Environmental Geochem and Health 43: 1-18. https://doi.org/10.1007/s10653-021-00898-y

[20] Corredor, J. A. G., Pérez, E. H., Figueroa, R., Casas, A. F. (2021). Water quality of streams associated with artisanal gold mining; Suárez, Department of Cauca, Colombia. Heliyon 7: 07047-07064. https://doi.org/10.1016/j.heliyon.2021.e07047.

[21] Santana, C. S., Olivares, D. M. M., Silva, V. H. C., Luzardo, F. H. M., Velasco, F. G., de Jesus, R. M. (2020). Assessment of water resources pollution associated with mining activity in a semi-arid region. Journal of Environmental Management 273: 1-13. https://doi.org/10.1016/j.jenvman.2020.111148

[22] Kim, D. M., Yun, S. T., Cho, Y., Hong, J. H., Batsaikhan, B., Oh, J. (2017). Hydrochemical assessment of environmental status of surface and ground water in mine areas in South Korea: Emphasis on geochemical behaviors of metals and sulfate in ground water. Journal of Geochemical Exploration 183: 33-45. http://dx.doi.org/10.1016/j.gexplo.2017.09.014.

[23] Sahoo, S., Khaoash, S. (2020). Impact assessment of coal mining on groundwater chemistry and its quality from Brajrajnagar coal mining area using indexing models. Journal of Geochemical Exploration 215: 1-17. https://doi.org/10.1016/j.gexplo.2020.106559

[24] Molina-Villalba, I., Marina, L., Rodríguez-Barranco, M.,
Hernández, A. F., Gonzalez-Alzaga, B., Aguilar-Garduño, C., Fernando, G. (2015). Biomonitoring of arsenic, cadmium, lead, manganese and mercury in urine and hair of children living near mining and industrial areas. Chemosphere 124: 83-91. https://doi.org/10.1016/j.chemosphere.2014.11.016.

[25] Calao-Ramos, C., Bravo, A. G., Paternina-Uribe, R., MarrugoNegrete, J., Díez, S. (2021). Occupational human exposure to mercury in artisanal small-scale gold mining communities of Colombia. Environment International 146: 1-10. https://doi.org/10.1016/j.envint.2020.106216.

[26] Ngure, V., Lelo, F., Obwanga, B. (2017). Heavy Metal Pollution from Migori Gold Mining Area, Kenya: Health Implications for Consumers of Fish and Water. Journal of Natural Sciences Research 7: 46-53.

[27] Basu, N., Clarke, E., Green, A., Calys-Tagoe, B., Chan, L., Dzodzomenyo, M., Fobil, J., Long, R. N., Neitzel, R. L., Obiri, S., Odei, E., Ovadje, L., Quansah, R., Rajaee, M., Wilso, M. L. (2015). Integrated Assessment of Artisanal and Small-Scale Gold Mining in Ghana-Part 1: Human Health Review. International Journal of Environmental Research and Public Health 12: 5143-5176; https://doi.org/10.3390/ijerph120505143.

[28] Akpanowo, M. A., Bello, N. A., Umaru, I., Iyakwari, S., Joshua, E., Yusuf, S., Ekong, G. B. (2021). Assessment of radioactivity and heavy metals in water sources from Artisanal mining areas of Anka, Northwest Nigeria. Scientific African 12: 1-11. https://doi.org/10.1016/j.sciaf.2021.e00761.

[29] Samson, I. O., Muruf, A. K., Priscilla, O., Joseph, A. (2013). Mercury contamination in artisanal gold mining area of Manyera river, niger state Nigeria. Journal of Environmental Research and Management 4: 326-333.

[30] Gyamfi, E., Appiah-Adjeia, E. K., Adjei, K. A. (2019). Potential heavy metal pollution of soil and water resources from artisanal mining in Kokoteasua, Ghana. Groundwater for Sustainable Development 8: 450-456. https://doi.org/10.1016/j.gsd.2019.01.007

[31] Kortei, N. K., Heymann, M. E., Essuman, E. K., Kpodo, F. M., Akonor, P. T., Lokpo, S. Y., Boadi, N. O., Ayim-Akonor, M., Tettey, C. (2020). Health risk assessment and levels of toxic metals in fishes (Oreochromis noliticus and Clarias anguillaris) from Ankobrah and Pra basins: Impact of illegal mining activities on food safety. Toxicology Reports 7: 360-369. https://doi.org/10.1016/j.toxrep.2020.02.011

[32] Bempah, C. K., Voigt, H. J., Ewusi, A. (2016). Impact of mining on groundwater quality in SW Ashanti, Ghana: a preliminary study. Journal of mining and environnemental 7: 81-95. https://doi.org/10.22044/jme.2016.496

[33] Niane, B., Guédron, S., Feder, F., Legros, S., Ngom, P. M., Moritz, R. (2019). Impact of recent artisanal small-scale gold mining in Senegal: Mercury and methylmercury contamination of terrestrial and aquatic ecosystems. Sciences of the Total Environment 669: 185-193. https://doi.org/10.1016/j.scitotenv.2019.03.108

[34] Ouédraogo, O., Amyot, M., (2013). Mercury, arsenic and selenium concentrations in water and fish from sub-Saharan semi-arid freshwater reservoirs (Burkina Faso). Sciences of the Total Environment 444: 243-254. http://dx.doi.org/10.1016/j.scitotenv.2012.11.095 
[35] Kone, K., Kouakou, A. R., Konan, E. K., Adouby, K., (2019). Heavy Metal Pollution Index of Surface Water and Groundwater Around Tongon Mine (Côte d'Ivoire). International Journal of Environmental Monitoring and Analysis 7: 103-111. http://dx.doi.org/10.11648/j.ijema.20190705.12

[36] Ouattara, A. A., Yao, K. M., Soro, M. P., Diaco, T., Trokourey, A. (2018). Arsenic and Trace Metals in Three West African rivers: Concentrations Partitioning, and Distribution in Particle-Size Fractions. Archives of Environmental Contamination and Toxicology 75: 449-463. https://doi.org/10.1007/s00244-018-0543-9

[37] Soro, M. P., Yao, K. M., Kouassi, N. L. B., Ouattara, A. A., Diaco, T. (2020). Modeling the Spatio-Temporal Evolution of Chlorophyll-a in Three Tropical Rivers Comoé, Bandama, and Bia Rivers (Côte d'Ivoire) by Artificial Neural Network. Wetlands 40: 939-956. https://doi.org/10.1007/s13157-02001284-7

[38] Girard, G., Sircoulon, J., Touchebeuf, P. (1970). Aperçu sur les régimes hydrologiques de Côte d'Ivoire. ORSTOM Editions, Côte d'Ivoire.

[39] Fabio, P., Njifonjou, O., Assienan, J., Kodjo, A., Ndia, Y., Salvati, N., Seghieri, C. (2002). Profil de pauvreté des communautés riveraines du lac de Kossou en Côte d'Ivoire. Cotonou, Programme pour des Moyens d'Existence Durables dans la Pêche en Afrique de l'Ouest, 90p. PMEDP/RT/17.

[40] APHA. (2002). Standard Methods for the Examination of Water and Waste Water. APHA, Washington, DC, USA

[41] Prathap, A., Chakraborty, S. Hydro chemical characterization and suitability analysis of groundwater for domestic and irrigation uses in open cast coal mining areas of Charhi and Kuju, Jharkhand, India. Groundwater for Sustainable Development 9: 100244-100284. https://doi.org/10.1016/j.gsd.2019.100244

[42] Gupta, A., Singh, R., Singh, P., Dobhal, R. (2017). Heavy Metals in Drinking Water Sources of Dehradun, Using Water Quality Indices. Analytical Chemistry Letters 7: 509-519. https://doi.org/10.1080/22297928.2017.1372209

[43] Ali, R., Hassani, H., Hayati, M., Jabbari, N., Barzegar, R. (2018). Risk assessment and ranking of heavy metals concentration in Iran's Rayen groundwater basin using linear assignment method. Stochastic Environmental Research and Risk Assessment 32: 1317-1336. http://dx.doi.org/10.1007/s00477-017-1477-x

[44] World Health Organization. (2017). Guidelines for drinking water quality, 4th edn. Recommendations, WHO, Geneva

[45] US Environmental Protection Agency. (2018). Edition of the Drinking Water Standards and Health Advisories, Washington, DC, USA

[46] Karaouzas, I., Kapetanaki, N., Mentzafou, A., Kanellopoulos, T. D., Skoulikidis, N. (2021). Heavy metal contamination status in Greek surface waters: A review with application and evaluation of pollution indices. Chemosphere 263: 1-15. https://doi.org/10.1016/j.chemosphere.2020.128192

[47] Hossain, M., Patra, P. K. (2020). Contamination zoning and health risk assessment of trace elements in groundwater through geostatistical modelling. Ecotoxicology and
Environmental Safety 189:

https://doi.org/10.1016/j.ecoenv.2019.110038

$1-11$.

[48] Dippong, T., Mihali, C., Hoaghia, M. A., Cical, E., Cosma, A. (2019). Chemical modeling of groundwater quality in the aquifer of Seini town - Some Plain, Northwestern Romania. Ecotoxicology and Environmental Safety 168: 88-101. https://doi.org/10.1016/j.ecoenv.2018.10.030

[49] Sener, S., Sener, E., Davraz, A. (2017). Evaluation of water quality using water quality index (WQI)method and GIS in Aksu River (SW-Turkey). Sciences of the Total Environment 584-585:

http://dx.doi.org/10.1016/j.scitotenv.2017.01.102

$131-144$.

[50] Xiao, J., Wang, L., Deng, L., Jin, Z. (2019). Characteristics, sources, water quality and health risk assessment of trace elements in river water and well water in the Chinese Loess Plateau. Science of The Total Environment 650. 2004-2012. https://doi.org/10.1016/j.scitotenv.2018.09.322

[51] Zhang, Y., Chu, C., Li, T., Xu, S., Liu, L., Ju, M. (2017). A water quality management strategy for regionally protected water through health risk assessment and spatial distribution of heavy metal pollution in 3 marine reserves. Sciences of the Total Environment 599-600: 721-731. http://dx.doi.org/10.1016/j.scitotenv.2017.04.232

[52] US Environmental Protection Agency. (2004). Risk Assessment Guidance for Superfund, Vol. 1, Human Health Evaluation Manual. Part E (supplemental guidance for dermal risk assessment), EPA/540/R/99/005. Office of Superfund Remediation and Technology Innovation, Washington, DC, USA

[53] US Environmental Protection Agency. (2013). Regional screening level (RSL) summary Table. http://www.epa.gov/reg3hwmd/risk/human/rbconcentration table/Generic

Tables/docs/master_sl_table_run_NOV2013.pdf. Accessed November 2013.

[54] World Bank. (2019). The World Bank Group: Average Life Expectancy in Côte d'Ivoire: 2009- 2019. https://data.worldbank.org/indicator/SP.DYN.LE00.IN?locatio ns $=$ CI. Accessed 12 Jully 2021

[55] OEHHA. (2019). California Office of Environmental Health Hazard Assessment (OEHHA). Technical Support Document for Cancer Potency Factors 2009, Appendix A: Hot Spots Unit Risk and Cancer Potency Values. Updated May 2019.

[56] Pecina, V., Brtnický, M., Baltazár, T., Juřička, D., Kynický, J., Galiová, M. V. (2021). Human health and ecological risk assessment of trace elements in urban soils of 101 cities in China: A meta-analysis. Chemosphere 267: 1-42. https://doi.org/10.1016/j.chemosphere.2020.129215

[57] Kaur, M., Kumar, A., Mehra, R., Kaur, I. (2019). Quantitative assessment of exposure of heavy metals in groundwater and soil on human health in Reasi district, Jammu and Kashmir. Environmental Geochem and Health 42: 77-94. https://doi.org/10.1007/s10653-019-00294-7

[58] Kinimo, K. C., Yao, K. M., Marcotte, S., Kouassi, N. B. L., Trokourey, A. (2018). Distribution trends and ecological risks of arsenic and trace metals in wetland sediments around gold mining activities in central-southern and southeastern Côte d'Ivoire. Journal of Geochemical Exploration 190: 265-280. https://doi.org/10.1016/j.gexplo.2018.03.013 
[59] Varol, S., Davraz, A. (2015). Evaluation of the groundwater quality with WQI (Water Quality Index) and multivariate analysis: a case study of the Tefenni plain (Burdur/ Turkey). Environmental Earth Sciences 73: 1725-1744. https://doi.org/10.1007/s12665-014-3531-z.

[60] Sunitha, V., Sudharshan, R. Y. (2019). Hydrogeochemical evaluation of groundwater in and around Lakkireddipalli and Ramapuram, Y. S. R District, Andhra Pradesh. India. HydroResearch. $\quad 2$ 85-96. https://doi.org/10.1016/j.hydres.2019.11.008.

[61] Sharmin, S., Mia, J., Miah, M. S., Zakir, H. M. (2020). Hydrogeochemistry and heavy metalcontamination in groundwaters of Dhaka metropolitan city, Bangladesh: Assessment of human health impact. HydroResearch 3: 106117. https://doi.org/10.1016/j.hydres.2020.10.003.

[62] Lü, J., Jiao, W. B., Qiu, H. Y., Chen, B., Huang, X. X., Kang, B. (2018). Origin and spatial distribution of heavy metals and carcinogenic risk assessment in mining areas at You'xi County southeast China. Geoderma 310: 99-106. http://dx.doi.org/10.1016/j.geoderma.2017.09.016.
[63] Luo, X. S., Xue, Y., Wang, Y. L., Cang, L., Xu, B., Ding, J. (2015). Source identification and apportionment of heavy metals in urban soil profiles. Chemosphere 127: 152-157. http://dx.doi.org/10.1016/j.chemosphere.2015.01.048.

[64] Xia, F., Qu, L., Wang, T., Luo, L., Chen, H., Randy, A., Dahlgren, R. A., Zhang, M., Mei, K., Huang, H. (2018). Distribution and source analysis of heavy metal pollutants in sediments of a rapid developing urban river system. Chemosphere 207: 218-228. https://doi.org/10.1016/j.chemosphere.2018.05.090.

[65] Singh, U.K., Ramanathan, A. L., Subramanian, V. (2018). Groundwater chemistry and human health risk assessment in the mining region of East Singhbhum, Jharkhand, India. Chemosphere 204: 501-513. https://doi.org/10.1016/j.chemosphere.2018.04.060.

[66] Kim, H. S., Kim, Y. J., Seo, Y. R. (2015). An Overview of Carcinogenic Heavy Metal: Molecular Toxicity Mechanism and Prevention. Journal of Cancer Prevention 20: 232 - 240. http://dx.doi.org/10.15430/JCP.2015.20.4.232. 